\title{
APLICAÇÃO DA TÉCNICA DE DAS-ELISA INDIRETO PARA DIAGNÓSTICO E ESTUDOS QUANTITATIVOS DO VÍRUS DO ENDURECIMENTO DOS FRUTOS DO MARACUJAZEIRO
}

\author{
QUELMO SILVA DE NOVAES \\ Engenheiro Agrônomo
}

Orientador: Prof. Dr. JORGE ALBERTO MARQUES REZENDE

Dissertação apresentada à Escola Superior de Agricultura "Luiz de Queiroz", Universidade de São Paulo, para obtenção do título de Mestre em Agronomia, Área de Concentração: Fitopatologia.

PIRACICABA

Estado de São Paulo - Brasil

Junho -1998 
Dados Internacionais de Catalogação na Publicação (CIP) DIVISÃo DE BIBLIOTECA E DOCUMENTAÇÃo - Campus "Luiz de Queiroz"/USP

Novaes, Quelmo Silva de

Aplicação da técnica de DAS-ELISA indireto para diagnóstico e estudos quantitativos do vírus do endurecimento dos frutos do maracujazeiro / Quelmo Silva de Novaes. - - Piracicaba, 1998.

61 p. : il.

Dissertação (mestrado) - - Escola Superior de Agricultura Luiz de Queiroz, 1998. Bibliografia.

1. DAS-ELISA 2. Doença de planta 3. Endurecimento-dos-frutos-domaracujazeiro 4. Fitopatologia 5. Técnica serológica I. Titulo 
A meus pais, Heleno e Carmosina, meus irmãos, Juca e Núbia, pelo apoio e compreensão, com amor, 


\section{AGRADECIMENTOS}

A Deus, pela constante presença em nossas vidas;

Ao Prof. Dr. Jorge A. M. Rezende, pela orientação desta dissertação e pelo incentivo, confiança, paciência e amizade e, pelos conhecimentos transmitidos durante a realização deste trabalho;

Ao Prof. Elliot W. Kitajima e à Prof. Lilian Amorim, pelas sugestões e revisão desta dissertação;

Ao técnico José Edivaldo Buriolla, pelo auxilio prestado no laboratório de Virologia Vegetal do Departamento de Fitopatologia da ESALQ;

Ao Sr. Pedro C. Arthuso, pelo auxilio nos trabalhos desenvolvidos em casa de vegetação do Departamento de Fitopatologia da ESALQ;

Aos professores e funcionários do Departamento de Fitopatologia da ESALQ, pelos conhecimentos transmitidos e pela amizade surgida durante a elaboração deste trabalho;

Aos colegas do curso de Mestrado em Fitopatologia da ESALQ, por todo o apoio durante a realização deste estudo, em especial ao amigo Nelson Sidnei Massola Jr., pelo auxílio na análise dos dados dos experimentos;

Ao Prof. Abel Rebouças São José, da Universidade Estadual do Sudoeste da Bahia, pelo incentivo na realização deste trabalho;

Aos amigos Alcebiades Rebouças São José e Reginaldo Barros, por todo apoio e conselhos dados não só na minha adaptação como também no decorrer do curso de Mestrado e pelo auxílio no preparo de slides para apresentações;

À bibliotecária Eliana M. G. Sabino, pela revisão da bibliografia desta dissertação;

Ao Prof. Marcelo A. Pavan, da UNESP/Botucatu, pelo fornecimento de coelhos e ao Departamento de Genética, da ESALQ/USP, pelo fornecimento da galinha, para produção de antissoros utilizados durante este trabalho; 
Ao Conselho Nacional de Desenvolvimento Científico e Tecnológico (CNPq), pela concessão de bolsa de estudos durante o curso de Mestrado;

Ao Serviço Social da ESALQ, pela concessão de moradia durante o curso de Mestrado;

Aos meus amigos e irmãos da Vila Estudantil, os quais se fizeram presentes em todos os momentos, não só de alegrias mas também de dificuldades;

$\grave{A}$ todos aqueles que direta ou indiretamente contribuíram para a realização deste trabalho;

Finalmente, agradeço à minha família e a Luciana Cantarelli, por todo o carinho, incentivo e compreensão. 


\section{SUMÁRIO}

Página

LISTA DE FIGURAS ................................................................... vii

LISTA DE QUADROS ............................................................ ix

RESUMO

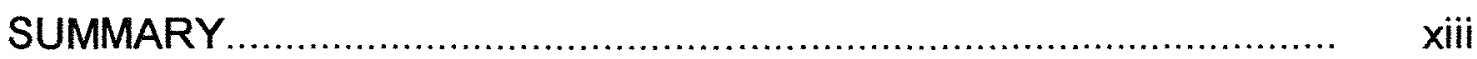

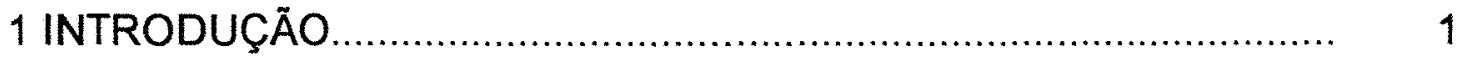

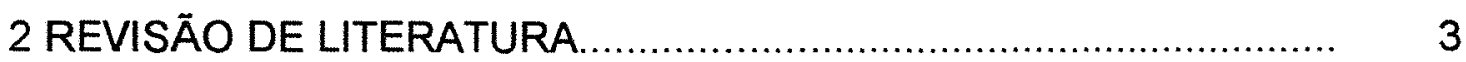

2.1 Generalidades sobre o vírus do endurecimento dos frutos............. 3

2.2 Estudos quantitativos de vírus em plantas..................................... 5

3 MATERIAL E MÉTODOS............................................................ 10

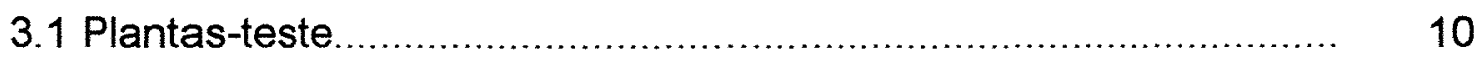

3.2 Isolados do PWV .................................................................... 10

3.3 Inoculação mecânica do PWV ....................................................... 11

3.4 Escala de notas de sintomas.................................................. 11

3.5 Purificação do PWV ................................................................... 12

3.6 Produção de antissoros............................................................... 13

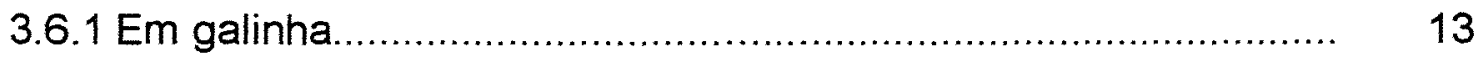

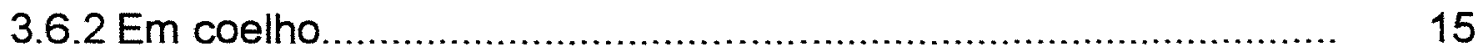

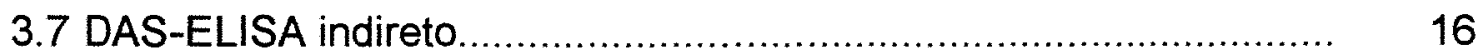

3.7.1 Padronização do método........................................................... 16

3.7.2 Para fins de diagnóstico........................................................ 18

3.7.3 Para fins quantitativos ....................................................... 19

3.8 Análise de correlação entre notas de sintomas e concentração do

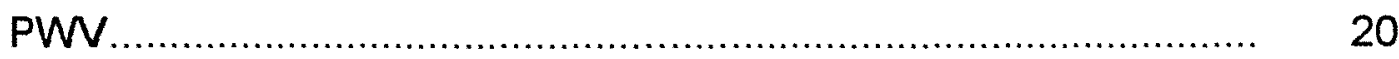

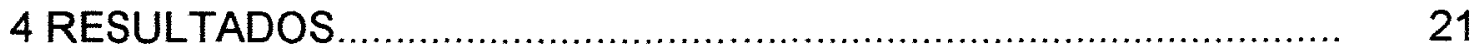

4.1 Purificação do PWW ..................................................................... 21

4.2 Obtenção de antissoros para o PWW........................................... 23 
4.3 Padronização do teste de DAS-ELISA indireto................................ 23

4.4 Sensibilidade do DAS-ELISA indireto para a detecção do PWW..... 27

4.5 Obtenção da equação de regressão linear utilizada na quantifica-

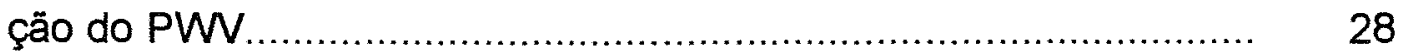

4.6 Quantificação do PWV através do teste de DAS-ELISA indireto.... $\quad 30$

5 DISCUSSÃO

5.1 Purificação do PWW ................................................................. 37

5.2 Produção de antissoros para o PWV ............................................... 38

5.3 Padronização do DAS-ELISA indireto............................................ 39

5.4 Sensibilidade do DAS-ELISA indireto........................................... 40

5.5 Estimativa da concentração do PWV ............................................. 41

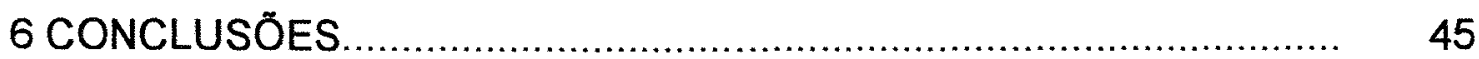

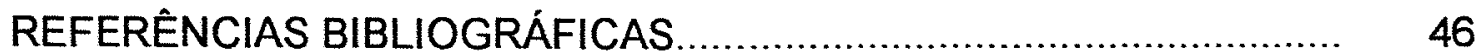

APÊNDICE 


\section{LISTA DE FIGURAS}

Página

1. Diagrama da distribuição e concentrações das IgG e lgY e distribuição das amostras infectadas com o PWV e sadias, em uma parte da placa de ELISA. Cada retângulo representa dois pocinhos da placa. Água foi acrescentada no momento de zerar o leitor de ELISA

2. Espectro de absorção ultravioleta $(230-320 \mathrm{~nm})$ da preparação purificada do PWV, obtida a partir de plantas de feijão-de-porco infectadas.

3. Micrografia eletrônica de uma preparação purificada do PWV contrastada negativamente com acetato de uranila $1 \%$, contendo grupos de partículas alongadas típicas de potyvirus.

4. Valores médios de absorbância $\left(A_{405}\right)$ obtidos na padronização do teste de DAS-ELISA indireto, utilizando diferentes concentrações de IgG e IgY, respectivamente, para a captura do PWW e para completar o sanduíche da reação sorológica

5. Valores médios de absorbância $\left(A_{405}\right)$ obtidos na padronização do teste de DAS-ELISA indireto, utilizando diferentes concentrações de IgY e IgG, respectivamente, para a captura do PWV e para completar o sanduíche da reação sorológica

6. Valores de absorbância $\left(A_{405}\right)$ obtidos em dois testes para avaliar a sensibilidade do DAS-ELISA indireto para a detecção de diferentes concentrações do PWV

7. Relação de linearidade entre valores de absorbância $\left(A_{405}\right)$ e concentrações conhecidas do PWV purificado 
8. Concentração estimada do PWV em planta de 3 espécies de maracujazeiro inoculadas com o isolado de Vera Cruz, com respectivas notas de sintomas (1= sem sintomas aparente de mosaico; 2= mosaico leve e $3=$ mosaico severo, deformações foliares e bolhas).

9. Concentração estimada do PWV em plantas de $P$. edulis f. flavicarpa, inoculadas com os isolados de Vera Cruz (VC), Brasília (B) e Minas Gerais (MG), com respectivas notas de sintomas (1= sem sintomas aparente de mosaico; $2=$ mosaico leve e $3=$ mosaico severo,

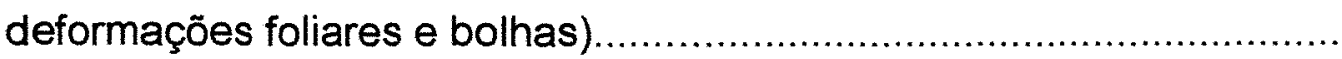

10. Concentração estimada do PWW em plantas de C. juncea, inoculadas com os isolados de Vera Cruz (VC), Brasilia (B) e Minas Gerais (MG), com respectivas notas de sintomas ( $1=$ sem sintomas aparente de mosaico; $2=$ mosaico leve e $3=$ mosaico severo, deformações foliares e bolhas).

11. Concentração estimada do $P W V$ em plantas de $P$. vulgaris $\mathrm{cv}$. Black Turtle 2, inoculadas com os isolados de Vera Cruz (VC), Brasília (B) e Minas Gerais (MG), com respectivas notas de sintomas (1= sem sintomas aparente de mosaico; $2=$ mosaico leve e $3=$ mosaico severo, deformações foliares e bolhas) 


\section{LISTA DE QUADROS}

Página

1. Coeficientes de correlação entre concentrações do PWV nos tecidos e notas de sintomas para as plantas de diferentes espécies infectadas com os isolados de Vera Cruz (VC), Brasilia (B) e Minas Gerais (MG). 


\title{
APLICAÇÃO DA TÉCNICA DE DAS-ELISA INDIRETO PARA DIAGNÓSTICO E ESTUDOS QUANTITATIVOS DO VÍRUS DO ENDURECIMENTO DOS FRUTOS DO MARACUJAZEIRO
}

\author{
Autor: QUELMO SILVA DE NOVAES \\ Orientador: Prof. JORGE ALBERTO MARQUES REZENDE
}

\section{RESUMO}

O vírus do endurecimento dos frutos ("Passionfruit woodiness virus" PWV) é um dos principais vírus que causam problemas à cultura do maracujazeiro em diversas regiões do país e do mundo.

Neste trabalho estudou-se a aplicação da técnica de DAS-ELISA indireto, com anticorpos produzidos em coelho e galinha, para fins de diagnóstico e estudos quantitativos do PWV.

Um isolado do PWV obtido de plantas de maracujazeiro de Vera Cruz, SP, foi purificado a partir de plantas de feijão-de-porco (Canavalia ensiformis D. C.), com produção média de $1,82 \mathrm{mg}$ de vírus por $100 \mathrm{~g}$ de tecido. Suspensões do PWV purificado foram injetadas em coelho da raça Nova Zelândia e em galinha da linhagem IPEG, na proporção de $100 \mu \mathrm{g}$ de vírus por injeção. As injeções, num total de 6 para $\circ$ coelho e de 3 para a galinha, foram intramusculares e a intervalos de duas e uma semana, respectivamente. A IgG do antissoro obtida do coelho foi purificada por meio da precipitação com 
sulfato de amônio saturado e cromatografia de troca iônica. A lgY do antissoro da galinha foi obtida diretamente a partir da gema do ovo.

Os testes para a padronização do DAS-ELISA indireto foram feitos com diferentes concentrações de IgG e de lgY, em diferentes combinações. Considerou-se positiva toda a reação cujo valor da absorbância foi superior ao dobro da média da absorbância do extrato da planta sadia (controle). Nessa condição, os melhores resultados foram obtidos utilizando-se $10 \mu \mathrm{g} / \mathrm{ml}$ da lgG para a captura do antígeno (PWV) e $1 \mu \mathrm{g} / \mathrm{ml}$ da $\mathrm{lg} Y$ para completar o sanduíche da reação sorológica.

Avaliações da sensibilidade do DAS-ELISA indireto, foram feitas com concentrações conhecidas do vírus purificado $(10,20,40,80,160,320,640$, $1.280,2.560$ e $5.120 \mathrm{ng} / \mathrm{ml}$ ) e utilizando-se o mesmo critério acima mencionado para separar reações positivas e negativas. Nessas condições a técnica foi altamente sensivel para a detecção de até $20 \mathrm{ng} / \mathrm{ml}$.

Para os estudos quantitativos do PWW foram utilizadas plantas de Passiflora edulis f. flavicarpa, P. giberti, P. cincinnata, Crotalaria juncea e Phaseolus vulgaris cv. Black Turtle 2. As plantas foram inoculadas mecanicamente com três isolados do PWV (Vera Cruz, Brasília e Minas Gerais), separadamente, e mantidas em casa de vegetação. Quinze dias depois foram retiradas amostras de três folhas desenvolvidas de cada planta e maceradas em PBS-Tween, na diluição de 1:500. As amostras foram testadas através do DAS-ELISA indireto, juntamente com as mesmas concentrações conhecidas do PWV purificado. Os valores médios de absorbância obtidos para cada concentração conhecida do vírus foram utilizados para obtenção de uma equação de regressão linear para posterior quantificação do vírus. As concentrações do PWV nas diferentes espécies, estimadas em $\mu \mathrm{g} / \mathrm{g}$ de tecido, variaram de aproximadamente 61,0 a $1.232,5$ para $P$. edulis f. flavicarpa, de 45,0 a 669,5 para $P$. giberti, de 25,0 a $1.820,0$ para $P$. cincinnata, de 43,8 a 99,1 para $C$. juncea e de 48,4 a 84,6 para $P$. vulgaris cv. Black Turtle 2 . 
Diante desses resultados, sugere-se a utilização da técnica de DASELISA indireto nos trabalhos de diagnóstico do endurecimento dos frutos e nos estudos de seleção preliminar de plantas de maracujazeiro resistentes e/ou tolerantes à doença, através da quantificação do vírus nos tecidos das mesmas. 


\title{
APPLICATION OF INDIRECT DAS-ELISA FOR DIAGNOSIS AND QUATITATIVE STUDIES WITH PASSIONFRUIT WOODINESS VIRUS.
}

\author{
Author: QUELMO SILVA DE NOVAES \\ Adviser: Prof. JORGE ALBERTO MARQUES REZENDE
}

\section{SUMMARY}

Passionfruit woodiness virus (PWV) is the most important virus on passionfruit crops in several states of Brazil and in other parts of the world.

Studies were made to evaluate the practical application of the indirect DAS-ELISA, using antibodies produced in two different species of animals, for diagnosis and quantitative studies with PWV

A PWV isolate collected in Vera Cruz county, State of São Paulo, was purified from systemically infected Canavalia ensiformis (Leguminosae), with an average yield of $1.82 \mathrm{mg}$ of virus per gram of tissue. Purified virus was injected in New Zealand rabbit and chicken (line IPEG), using $100 \mu \mathrm{g}$ of virus per injection. A total of 6 injections for the rabbit and 3 for the chicken were applied intramuscularly, at one week interval. Rabbit IgG was purified by precipitation with saturated ammonium sulfate followed by ion exchange chromatography. Chicken IgY (IgG) was directly purified from the yolk of the egg.

Indirect DAS-ELISA tests with different concentration of $\lg G$ and $\lg Y$, at different combinations, were carried out to establish the most sensitive and accurate design for the technique. Absorbance values higher than twice the average absorbance for the healthy control were considered positive. Under this circumstance, the best results were obtained using $10 \mu \mathrm{g} / \mathrm{ml}$ of $\mathrm{lgG}$ to coat the ELISA plate and $1 \mu \mathrm{g} / \mathrm{ml}$ of $\mathrm{IgY}$ to complete the double sandwich. 
Studies on the sensitivity of the indirect DAS-ELISA, using known concentrations of purified PWV (10, 20,40,80, 160,320,640, 1.280, 2.560 e $5.120 \mathrm{ng} / \mathrm{ml}$ ) and the same criterium mentioned previously for separation of positive and negative serological reactions were also done. Under this conditions it was found that the technique detected up to $20 \mathrm{ng}$ of virus $/ \mathrm{ml}$.

Quantitative evaluations of PWV were made on plants of Passiflora edulis f. flavicarpa, P. giberti, P. cincinnata, Crotalaria juncea and Phaseolus vulgaris cv. Black Turtle 2. Plants were inoculated separately with three isolates of PWV (Vera Cruz, Brasília and Minas Gerais), under greenhouse conditions. Discs from three expanded upper leaves of each plant were harvested fifteen days after inoculation and ground in PBS-Tween, diluted 1:500. All samples were tested on indirect DAS-ELISA, using the same known concentrations of purified PWW as standard. Absorbance values obtained with the standard concentrations of PWW were used for linear regression analysis and further estimation of the virus present in the samples. Estimated concentrations of PWV ( $\mu \mathrm{g} / \mathrm{g}$ of tissue) varied from 61.0 to $1,232.0$ for $P$. edulis f. flavicarpa, from 45.0 to 669.5 for $P$. giberti, from 25.0 to $1,820.0$ for $P$. cincinnata, from 43.8 to 99.1 for $C$. juncea and from 48.4 a 84.6 for $P$. vulgaris cv. Black Turtle 2.

Based on these data it is suggested the use of indirect DAS-ELISA for diagnosis of passionfruit woodiness and preliminary screening of passionfruit plants resistant or tolerant to the disease, based on the concentration of virus in their tissue. 


\section{INTRODUÇÃO}

Maracujá é o nome geral dado ao fruto de várias espécies tropicais e subtropicais do gênero Passiflora, compondo cerca de 600 espécies (Salomão \& Andrade, 1987), sendo os mais cultivados o amarelo (Passiflora edulis $\mathrm{f}$. flavicarpa Deg.) e o roxo ( $P$. edulis Sims).

Os maiores produtores mundiais de maracujá estão localizados na América do Sul, onde o Brasil aparece em primeiro lugar, com uma área estimada em 24.000 ha (Ruggiero et al., 1996). Todo o maracujá produzido no Brasil tem sido destinado à produção de suco e à comercialização de frutas frescas.

Muitos são os problemas que afetam a produção e a qualidade dos frutos do maracujazeiro, como variabilidade genética, pragas e doenças, entre as quais estão as viroses. Dentre as viroses e anomalias correlatas constatadas em diversas zonas produtoras de maracujá do país, destaca-se aquela causada pelo vírus do endurecimento dos frutos ("Passionfruit woodiness virus" - PWV )( Kitajima et al., 1986). O PWW foi constatado pela primeira vez em plantas comerciais de maracujá amarelo e Passiflora alata, no Estado da Bahia, no final da década de 70 (Chagas et al., 1981 e Yamashiro \& Chagas, 1979). Posteriormente foi relatado nos Estados de Pernambuco (Loreto \& Vital, 1983), Sergipe, Ceará (Kitajima et al., 1986), São Paulo (Chagas et al., 1992), Minas Gerais (São José et al., 1994) e no Distrito Federal (Inoue et al., 1995). 
Todos aqueles que escreveram sobre o endurecimento dos frutos do maracujazeiro no Brasil, o fizeram no sentido de relatar a ocorrência da doença e apresentar recomendações gerais de controle, geralmente com base em trabalhos realizados em outros países. Não há, até o momento, relatos de trabalhos brasileiros que procuraram avaliar os danos e as perdas causadas pelo PWV à cultura do maracujazeiro, bem como desenvolver medidas de controle para as condições locais. Diante desse fato, o presente trabalho teve por objetivo estudar a aplicação da técnica sorológica de DAS-ELISA indireto para quantificação do PWV em tecidos de plantas infectadas, no sentido de apresentar subsídios para posteriores trabalhos de seleção de plantas de maracujazeiro resistentes e/ou tolerantes à doença. Além disso, procurou-se avaliar a sensibilidade dessa técnica para fins de diagnóstico, para que possa ser usada em clínicas fitopatológicas, bem como em estudos que requeiram a indexação das plantas infectadas. 


\section{REVISÃO DE LITERATURA}

\subsection{Generalidades sobre o virus do endurecimento dos frutos}

O vírus do endurecimento dos frutos do maracujazeiro encontrado no Brasil apresenta características semelhantes às descritas na Austrália, onde ele foi primeiramente relatado (McKnight, 1953). O PWW, como é conhecido internacionalmente, é uma espécie do gênero Potyvirus, da família Potyviridae, cujas partículas medem $670-750 \mathrm{~nm}$ de comprimento por $12-15 \mathrm{~nm}$ de diâmetro (Murphy et al., 1995). Apresenta RNA de fita simples, positiva, e produz no citoplasma das células infectadas inclusões lamelares típicas dos Potyvirus, na configuração de catavento (Taylor \& Greber, 1973).

A transmissão natural do PWW em campo se dá por meio de afídeos, principalmente pelas espécies Myzus persicae Sulz. e Aphis gossypii Glover (Chagas et al., 1981), sendo a relação vírus-vetor do tipo não persistente (Taylor \& Graber, 1973). Até o momento não se têm relatos de transmissão por sementes em espécies de maracujazeiro, mas o PWW foi transmitido por sementes de feijoeiro (Phaseolus vulgaris L.) cv. Preto 153 (Costa, 1985). Experimentalmente a transmissão mecânica é relativamente fácil, sendo transmitido para várias espécies de maracujazeiro, com exceção de $P$. suberosa, que parece ser imune (Costa, 1994). Além do maracujazeiro, o PWW também é capaz de infectar sistemicamente alguns feijoeiros, Canavalia 
ensiformis D. C., C. brasiliensis Marth., Crotalaria juncea L., Cassia occidentalis (L.) Link, amendoim, centrosema, entre outras espécies de leguminosas. Em outras espécies, como Chenopodium amaranticolor Coste \& Reyn, C. quinoa Willd. e $P$. vulgaris (cvs. Jalo e Manteiga), esse vírus causa apenas lesões locais nas folhas inoculadas.

Plantas de maracujazeiro infectadas com o PWW apresentam sintomas generalizados de mosaico foliar, com intensidade variável, podendo vir acompanhado de manchas anelares, bolhas, rugosidade e deformações do limbo foliar. As plantas afetadas podem apresentar ainda o crescimento retardado, bem como encurtamento dos entrenós. Os frutos podem ficar deformados e menores do que os produzidos por planta sadia, o pericarpo fica com espessura irregular e consistência endurecida, havendo redução na cavidade da polpa (Pio-Ribeiro \& Mariano, 1997 e Rezende, 1994). Não foram encontrados relatos sobre danos quantitativos causados pelo PWV a cultura do maracujazeiro no Brasil.

Em alguns países, como a Austrália, o controle dessa virose tem sido alcançado principalmente através da utilização de híbridos de maracujá roxo e amarelo, tolerantes à doença (Inch, 1978 e Taylor \& Greber, 1973). Em alguns casos o controle é obtido através da utilização dos híbridos tolerantes premunizados com estirpes fracas do PWV (Pares et al., 1985 e Peasley \& Fitzell, 1981), cujas pesquisas iniciais foram feitas por Simmonds (1959). Em Taiwan, o controle tem sido feito com a erradicação anual dos plantios afetados e replantio com mudas livres do vírus (Chang et al., 1992). No Brasil, já foram apontadas linhas de trabalho para o desenvolvimento de métodos de controle através da resistência ou tolerância (Chagas et al., 1992 e Kitajima et al., 1986), premunização com isolados fracos do vírus e práticas culturais que possam minimizar a incidência e a disseminação da doença. A exploração da variabilidade genética entre as espécies de Passiflora, e principalmente, dentro da espécie cultivada $P$. edulis f. flavicarpa poderá revelar fontes de resistência 
ou tolerância de grande valor para o controle da moléstia em campo. Da mesma forma, a obtenção de estirpes fracas do PWV, de valor protetivo, poderá ser uma outra alternativa valiosa para o controle do endurecimento dos frutos (Rezende, 1994). No entanto, até o momento, não são conhecidos resultados de trabalhos direcionados para estas finalidades.

\subsection{Estudos quantitativos de vírus em plantas}

O conhecimento da concentração de vírus no tecido vegetal oferece uma alternativa eficiente para a seleção de plantas resistentes ou tolerantes a viroses. Cita-se como exemplos, a seleção de cultivares de trigo (Triticum aestivum L.) resistentes ao vírus do mosaico ("Wheat soilborne mosaic virus" WSBMV) (Hunger et al., 1989); a seleção de plantas de alface (Lactuca sativa L.) resistentes ao virus do mosaico ("Lettuce mosaic virus" - LMV) (Pink et al., 1992); a determinação da concentração do "Tomato yellow learf curl virus" (TYLCV), em tomateiros (Lycopersicon esculentum Mill.) tolerantes à doença (Michelson et al., 1994); a seleção de cultivares de soja (Glycine max (L.) Merrill) tolerantes ao vírus do mosaico ("Soybean mosaic virus" - SMV) (Almeida, 1995a) entre outros.

A quantificação de vírus em tecido vegetal pode ser feita através de diferentes técnicas, como a contagem do número de lesões locais produzidas pelo extrato da planta infectada inoculado em hospedeiro hipersensivel, comparado com o número de lesões causadas por concentrações conhecidas do vírus (Cheo, 1970; Gokhale \& Bald, 1987 e Kleczkowski, 1950). Embora seja uma técnica simples e de baixo custo, ela é relativamente demorada, pois exige o preparo de plantas-teste e a espera para a manifestação de sintomas após a inoculação. Outra técnica que pode ser utilizada com o mesmo propósito é a 
contagem de partículas do vírus, presentes em diluições conhecidas, ao microscópio eletrônico de transmissão (Derrick, 1973; Gibb et al., 1989 e Hill, 1984). Essa técnica, além de ser demorada e permitir a avaliação de poucas amostras, só pode ser aplicada em laboratórios que dispõem de um microscópio eletrônico. Testes sorológicos, entre os quais o de ELISA ("Enzyme Linked Immunosorbent Assay"), nas diferentes configurações (Van Regenmortel \& Dubs, 1993), também podem ser úteis para a quantificação de vírus em tecidos de plantas. Além de serem simples e de baixo custo, permitem a avaliação de um grande número de amostras em um pequeno espaço de tempo (Barker \& Harrison, 1986; Souza-Dias, 1988; Gibb et al., 1989; Moore et al., 1982 e Rezende \& Sherwood, 1991). Além dos estudos quantitativos, as técnicas sorológicas também são de grande utilidade para a detecção de vírus e o diagnóstico de fitoviroses.

A técnica de DAS ("Double Antibody Sandwich") ELISA foi aplicada para avaliações de concentrações do vírus do mosaico do fumo ("Tobacco mosaic virus" - TMV) em plântulas, gemas e calos de fumo (Nicotiana tabacum L. cv. Samsun) infectados e cultivados "in vitro" (Cardin et al., 1983). Várias diluições de extratos de tecidos foram avaliadas comparativamente com a concentração padrão do vírus diluída entre 7 e $125 \mathrm{ng} / \mathrm{ml}$. A quantidade de TMV estimada em gemas e plântulas foi de 20 e 40 vezes maior do que em calos, respectivamente.

Utilizando a técnica sorológica de DAS-ELISA, Davergne et al. (1984) estimaram a concentração do vírus do mosaico do pepino ("Cucumber mosaic virus" - CMV) nos cultivares de melão SC (resistente) e Vedrantais (suscetivel). O vírus foi inoculado nas plantas em estádio cotiledonar, as amostras foram coletadas entre 6 e 7 dias após a inoculação, e a concentração do CMV foi estimada utilizando-se como referência uma preparação purificada do vírus com concentrações entre $30-250 \mathrm{ng} / \mathrm{ml}$. Os resultados obtidos indicaram que a concentração do CMV encontrada na cultivar $\mathrm{SC}$ foi 50 vezes menor do que em 
Vedrantais, indicando que aquele cultivar apresenta uma resistência à multiplicação do vírus nos tecidos.

Cardin et al. (1984) estudaram a aplicação do teste de DAS-ELISA para estimar a concentração do CMV, utilizando preparações estabilizadas do vírus, purificado a partir de plantas de fumo (Nicotiana tabacum L.). Como padrão foram utilizadas as seguintes concentraçōes do vírus purificado: $500 ; 250 ; 125$; 62,$5 ; 31,25$ e 15,625 ng/ml. Valores de absorbância a $405 \mathrm{~nm}$, obtidos com as concentrações pré estabelecidas, apresentaram um aumento linear entre as concentrações de 31,25 a $250 \mathrm{ng} / \mathrm{ml}$ do vírus purificado. Com base em uma equação de regressão linear obtida com esses valores, os autores concluíram que seria possível estimar a concentração de CMV presente em extratos de plantas infectadas.

Observações visuais de sintomas e avaliações de concentrações de vírus, determinada por eletroforese em gel de poliacrilamida, foram utilizadas por Hunger \& Sherwood (1985), para avaliação da resistência de 12 cultivares de trigo inoculados com o WSBMV. As avaliações foram feitas $2,4,8$ e 24 semanas após a inoculação. As maiores concentrações do WSBMV foram observadas nas plantas avaliadas 4 semanas após a inoculação. Baixas concentrações do WSBMV foram associadas aos cultivares resistentes Hawk e Newton, apresentando 13,6 e $23,7 \mu \mathrm{g} / \mathrm{g}$ de tecido fresco, respectivamente. 0 cultivar suscetivel Sage, apresentou uma concentração de $112,6 \mu \mathrm{g} / \mathrm{g}$ de tecido fresco. No entanto a correlação entre concentração de vírus e os sintomas apresentados pelas plantas foi baixa.

Moyer et al. (1985), compararam a multiplicação do vírus do mosaico da melancia 2 ("Watermelon mosaic virus 2" - WMV-2), em genótipos de melão suscetiveis e uma linhagem, denominada 91213, resistente. Foi utilizado o teste de DAS-ELISA para determinar a multiplicação semanal do vírus e a contagem de lesões locais induzidas pelo WMV-2 em Chenopodium amaranticolor, para monitorar o acúmulo e a infectividade do vírus. A contagem 
de lesões locais indicou que o inóculo extraído da linhagem 91213 causou um número de lesões $10-20 \%$ menor do que o daqueles extraídos dos genótipos suscetiveis. Foi verificado também, através dos valores de absorbância obtidos no teste de DAS-ELISA, que a concentração do WMV-2 encontrada na linhagem 91213 , oito semanas após a inoculação, foi em média 5,7 vezes menor do que a concentração encontrada nos genótipos suscetíveis. Os valores de absorbância a $405 \mathrm{~nm}$ foram de 0,09 para a linhagem 91213 e de 0,51 para os genótipos suscetiveis.

Kuhn et al. (1986), estudando a resistência de cultivares de caupi ao vírus do mosaico do feijoeiro do sul dos EUA ("Southern bean mosaic virus" SBMV), observaram uma correlação próxima entre a sintomatologia e o acúmulo do vírus nos tecidos das plantas, sendo a concentração determinada através de DAS-ELISA. Genótipos suscetiveis, com sintomas severos e redução no crescimento da planta apresentaram concentrações do vírus acima de $1.000 \mu \mathrm{g} / \mathrm{g}$ de tecido. Por outro lado, a concentração do vírus em cultivares resistentes foi 4-6 vezes menor, enquanto que naqueles altamente resistentes foi 10 vezes menor.

Estudos sobre a reação de cultivares de fumo (Nicotiana tabacum L.) resistente (Tennessee 86 ) e suscetivel (Kentucky 14) ao "Tobacco vein mottling virus" - TVMV, foram feitos por Gibb et al. (1989). Uma das variáveis utilizadas para avaliar a resistência das cultivares à replicação do vírus, foi a determinação da concentração do TVMV nos tecidos das plantas, utilizando para isso o teste de DAS-ELISA e a microscopia eletrônica de transmissão. As avaliações foram feitas $3,7,14$ e 21 dias após a inoculação. Através do teste de DAS-ELISA não foi possivel detectar a presença do TVMV no cultivar Tennessee 86, depois de 21 dias da inoculação. Após o mesmo período de tempo encontrou-se concentrações de até $500 \mathrm{ng} / \mathrm{g}$ de tecido no cultivar Kentucky 14. A contagem de partículas virais presentes em protoplastos das plantas, feita em microscópio eletrônico de transmissão, indicou que o cultivar 
Kentucky 14 continha 3 vezes mais partículas de TVMV do que o cultivar Tennessee 86. Segundo os autores, a falha do teste de ELISA na detecção do TVMV no cultivar Tennessee 86 , deve-se possivelmente à baixíssima concentração do vírus nos tecidos das plantas, conforme observado nos protoplastos através da microscopia eletrônica.

Murphy \& Kyle (1995) estudando a resistência de pimentão (Capsicum annuum L.) ao "Pepper mottle virus" (PepMoV), através da técnica de DASELISA direto, constataram que a concentração do vírus em folhas do cv. Avelar (resistente), foi mais de 16 vezes menor do que a encontrada em folhas do cultivar Numex R Naky (suscetivel). Os valores em absorbância a $405 \mathrm{~nm}$ foram de 0,109 e 1,791 para os cultivares Avelar e Numex R Naky, respectivamente.

Anderson et al. (1996) estudaram o comportamento da concentração do "Blackeye cowpea mosaic virus" (BICMV) e do CMV em plantas de caupi, quando inoculados sozinhos ou em mistura, dos 5 aos 20 dias após a inoculação. A avaliação foi feita com base na severidade dos sintomas, correlacionada com a concentração do vírus, determinada através de ELISA indireto. Os resultados obtidos mostraram que as plantas inoculadas na fase cotiledonar com o BICMV e o $\mathrm{CMV}$, separadamente ou em mistura, não apresentaram diferenças significativas entre as concentrações dos dois vírus. Quando inoculadas com o CMV ou O BICMV, separadamente, na folha trifoliolada, não foram observados sintomas severos, nem aumento na concentração dos vírus. No entanto, quando os dois vírus foram inoculados simultaneamente, a resistência desapareceu, as plantas apresentaram sintomas severos de mosaico e um aumento de 16 a 75 vezes na concentração de ambos os vírus. 


\section{MATERIAL E MÉTODOS}

\subsection{Plantas-teste}

Para fins de manutenção dos isolados do PWV e purificação do vírus, foram utilizadas plantas de maracujazeiro e feijão-de-porco (Canavalia ensiformis D. C.). Para os testes de estimativa de concentração do PWV em tecidos de plantas infectadas foram utilizados maracujazeiros $(P$. edulis $f$. flavicarpa, $P$. giberti N. E. Brown e $P$. cincinnata Mast), Phaseolus vulgaris L. (cv. Black turtle 2) e Crotalaria juncea L. As plantas-teste foram obtidas através de semeadura em vasos de alumínio cheios de terra misturada com composto orgânico e adubo mineral, previamente preparado e autoclavado a $121^{\circ} \mathrm{C}$ por 2 horas e mantidas sob condições de casa de vegetação no Departamento de Fitopatologia da ESALQ/USP. Periodicamente as plantas foram adubadas com sulfato de amônio.

\subsection{Isolados do PWV}

Foram utilizados 3 isolados do PWV obtidos de maracujazeiro em Vera Cruz (SP), Minas Gerais e Brasília, os quais foram mantidos em plantas da 
mesma espécie mantidas em casa de vegetação. Com a finalidade de manter fontes de inóculo de boa qualidade, os isolados foram freqüentemente transmitidos mecanicamente para novas plantas de maracujazeiro.

\subsection{Inoculação mecânica do PWV}

Os inóculos para a transmissão mecânica do PWV foram preparados em almofariz, macerando-se folhas infectadas em tampão de fosfato de potássio $0,02 \mathrm{M}, \mathrm{pH} 7,0$, na diluição de 1:20. As folhas das plantas-teste a serem inoculadas foram previamente polvilhadas com carborundum e o inóculo foi aplicado por meio de fricção das folhas com o indicador umedecido com o extrato vegetal obtido. No geral as plantas-teste foram inoculadas 15 a 20 dias após a germinação. Após a inoculação as folhas foram lavadas com água para retirar o excesso de inóculo e de abrasivo. As plantas foram mantidas em casa de vegetação para observação dos sintomas.

\subsection{Escala de notas de sintomas}

Todas as plantas-teste inoculadas foram periodicamente avaliadas quanto a manifestação de sintomas. Para isso utilizou-se de uma escala de notas de 1 a 3 , onde: 1 = sem sintomas aparentes de mosaico, $2=$ mosaico leve e sem deformações foliares e 3 = mosaico severo, bolhas e deformações foliares. 


\subsection{Purificação do PWV}

Para a purificação do PWV foi utilizado o isolado de Vera Cruz (SP), propagado em feijão-de-porco. Aproximadamente 50 plantas foram inoculadas com o isolado do virus proveniente das plantas de maracujazeiro infectadas. Quinze dias após a inoculação as folhas sistemicamente infectadas foram coletadas e imediatamente utilizadas para purificação, de acordo com o método descrito por Marinho \& Kitajima (1989) e Marinho et al., (1984), com algumas modificações. Inicialmente as folhas foram trituradas em liqüidificador em presença de tampão fosfato $0,5 \mathrm{M}, \mathrm{pH} 7,2$, contendo EDTA $0,01 \mathrm{M}$ e $0,75 \%$ de sulfito de sódio ( $1 \mathrm{~g}$ de folhas $/ 2 \mathrm{ml}$ de tampão). $O$ extrato foi coado em gaze, adicionado n-butanol (concentração final 8\%), e agitado durante 12 horas a $4^{\circ} \mathrm{C}$. Em seguida foi centrifugado a $2.000 \mathrm{~g}$ por $10 \mathrm{~min}$. $\mathrm{O}$ sobrenadante foi coletado e acrescentado $8 \%$ polietilenoglicol 6000 (PEG 6000). Após agitar durante 3 horas a $4^{\circ} \mathrm{C}$, a suspensão foi centrifugada a $4.300 \mathrm{~g}$ por 30 minutos. O precipitado foi dissolvido em tampão fosfato $0,1 \mathrm{M}, \mathrm{pH} 7,0$, contendo EDTA $0,001 \mathrm{M}\left(1 / 10\right.$ do volume inicial), agitado durante 1 hora a $4^{\circ} \mathrm{C}$ e centrifugado a $1.500 \mathrm{~g}$ por 10 minutos. O sobrenadante foi coletado e centrifugado a 100.000 g por 50 minutos. O precipitado foi dissolvido em tampão fosfato $0,1 \mathrm{M}, \mathrm{pH} 7,0$, contendo EDTA $0,001 \mathrm{M}$ e centrifugado a $2.000 \mathrm{~g}$ por 10 minutos. O sobrenadante foi coletado e centrifugado em gradiente isopicnico de cloreto de césio ( $\mathrm{CsCl}$ ), dissolvido a $15 \%$ e colocado sobre um colchão de $\mathrm{CsCl}$ a $53 \%$ (peso/peso), dissolvido em tampão fosfato $0,1 \mathrm{M}, \mathrm{pH} 7,0$, contendo EDTA 0,001 M. $O$ gradiente foi centrifugado a $100.000 \mathrm{~g}$, por 16 horas, a $6^{\circ} \mathrm{C}$. A banda contendo o vírus foi coletada com o auxílio de uma pipeta Pasteur. O volume obtido foi completado com 2 volumes de tampão fosfato $0,1 \mathrm{M}, \mathrm{pH} 7,0$, contendo EDTA 0,001 M. Em seguida acrescentou-se 5\% PEG 6000 e agitouse por 30 minutos a $4^{\circ} \mathrm{C}$. Essa suspensão foi centrifugada a $5.000 \mathrm{~g}$ por 10 


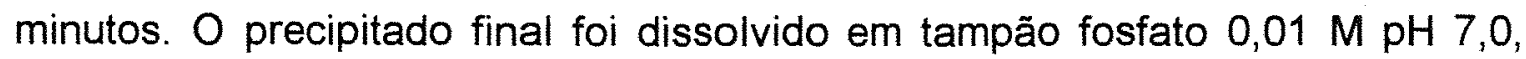
contendo EDTA 0,001 M. A preparação viral foi analisada em espectrofotômetro de luz ultravioleta, usando-se a faixa de comprimento de onda de 230 a $320 \mathrm{~nm}$. Para o cálculo da concentração do vírus foi utilizado o coeficiente de extinção $\left(E_{260}\right)$ de 2,4, obtido para o PWV (Chen, 1992). O PWV purificado foi armazenado a $4^{\circ} \mathrm{C}$.

A suspensão do vírus purificado foi transferida para telinhas de cobre cobertas com formvar e posteriormente contrastadas com acetato de uranila $1 \%$. As telinhas contendo o PWW purificado foram observadas em microscópio eletrônico de transmissão Zeiss EM 900 no NAP/MEPA, ESALQ/USP.

A preparação viral também foi testada quanto à infectividade, mediante à inoculação de plantas sadias de maracujazeiro ( $P$. edulis $f$. flavicarpa), $C$. amaranticolor e feijão-de-porco.

\subsection{Produção de antissoros}

\subsubsection{Em galinha}

Para a produção do antissoro foi utilizada uma galinha poedeira da Linhagem IPEG, fornecida pelo Departamento de Genética, ESALQ/USP. Inicialmente foram coletados ovos antes da primeira imunização, para obtenção de imunoglobulina normal. A galinha recebeu 3 imunizações com o vírus purificado, com intervalos de 1 semana entre cada uma. Cada imunização continha $100 \mu \mathrm{g}$ de vírus, em $200 \mu \mathrm{l}$ de suspensão emulsionada em igual volume de adjuvante incompleto de Freund. A emulsão foi injetada via intramuscular nas coxas da ave, alternando-se, a cada injeção, a coxa direita e 
a esquerda. Os ovos foram coletados a partir de uma semana após a última injeção, por um período de uma semana. A extração dos anticorpos presentes nas gemas dos ovos foi realizada com base na metodologia descrita por Polson et al. (1980).

Inicialmente, a gema foi separada da clara e lavada em água corrente de torneira. A membrana que envolve a gema foi rompida com o auxílio de um bastão de vidro e o seu conteúdo coletado em proveta para a aferição do volume. Em seguida, o seu conteúdo foi diluído em 4 volumes de tampão fosfato $0,1 \mathrm{M}, \mathrm{pH} 7,6$ e acrescentado 3,5\% PEG 6000 (peso/volume). A mistura foi mantida sob agitação constante por alguns minutos até completa dissolução do PEG 6000. Após centrifugação a $5.000 \mathrm{~g}$ por 10 minutos, o sobrenadante foi coletado e acrescido de mais $12 \%$ PEG 6000 . A mistura foi agitada por alguns minutos até completa dissolução do PEG 6000 e, em seguida, centrifugada a $5.000 \mathrm{~g}$ por 25 minutos. $O$ precipitado foi dissolvido em tampão fosfato $0,1 \mathrm{M}$, $\mathrm{pH} 7,6$, em volume igual a $1 / 4$ do volume inicial da gema, e resfriado até $0^{\circ} \mathrm{C} \mathrm{em}$ banho de gelo. Em seguida a solução foi misturada com igual volume de etanol $50 \%$ (volume/volume) pré-resfriado a $-20^{\circ} \mathrm{C}$. Após nova centrifugação a 10.000 $\mathrm{g}$ por 25 minutos, o precipitado foi dissolvido em tampão fosfato $0,1 \mathrm{M}, \mathrm{pH} 7,6$, em volume correspondente a $1 / 4$ do volume inicial da gema. A concentração de IgY foi estimada através da medida da absorbância a $280 \mathrm{~nm}$ em espectrofotômetro de luz ultravioleta. A IgY foi acondicionada em frascos de vidro e armazenada a $-20^{\circ} \mathrm{C}$. 


\subsubsection{Em coelho}

Para a produção de antissoro em coelho foi utilizado um animal da raça Nova Zelândia, com aproximadamente 4 meses de idade, gentilmente cedido pelo Biotério da UNESP, Botucatu, SP. Inicialmente foi coletada uma amostra de sangue do animal para obtenção de soro normal. A preparação viral purificada foi emulsionada com adjuvante incompleto de Freund em iguais proporções, sendo a mistura injetada via intramuscular na coxa do coelho. Quinzenalmente foi aplicado $1 \mathrm{ml}$ da emulsão contendo $100 \mu \mathrm{g}$ do vírus, num total de 6 imunizações. Dez dias após a última injeção, o sangue foi coletado semanalmente, por 2 semanas, através de cortes feitos na veia marginal da orelha do coelho. As amostras de sangue coletadas, com volume em torno de $25 \mathrm{ml}$ cada uma, foram colocadas para coagular a $4^{\circ} \mathrm{C}$ por 12 horas e, em seguida, centrifugadas a $3.000 \mathrm{~g}$ por 10 minutos, para a obtenção do soro sangüíneo. O soro coletado foi novamente centrifugado a $10.000 \mathrm{~g}$ por 10 minutos e transferido para recipientes de vidro, os quais foram etiquetados e armazenados a $-20^{\circ} \mathrm{C}$ (Bezerra et al., 1995).

A purificação da imunoglobulina $G(\mathrm{ggG})$ foi feita através da precipitação com solução saturada de sulfato de amônio e posterior passagem por coluna de cromatografia de troca iônica. $O$ volume de $1 \mathrm{ml}$ de antissoro foi inicialmente diluído em $9 \mathrm{ml}$ de água destilada. A seguir, sob agitação constante, foi lentamente adicionado $10 \mathrm{ml}$ de solução de sulfato de amônio saturado. Essa mistura foi incubada por 60 minutos, à temperatura ambiente e em seguida centrifugada a $10.000 \mathrm{~g}$ por 10 minutos. O precipitado foi dissolvido em $2 \mathrm{ml}$ de PBS ("Phosphate buffered saline") $1 / 2$ concentrado $\left(0,0015 \mathrm{M} \mathrm{KH}_{2} \mathrm{PO}_{4}, 0,14 \mathrm{M}\right.$ $\mathrm{NaCl}, 0,004 \mathrm{M} \mathrm{Na}_{2} \mathrm{HPO}_{4}, 0,003 \mathrm{KCl}, \mathrm{pH} \mathrm{7,4)}$. Foi feita diálise em PBS $1 / 2$ concentrado, a $4^{\circ} \mathrm{C}$, com 3 trocas de tampão, utilizando-se membrana de celulose com uma porosidade de 25 Angstrons. Após a diálise a solução foi 
submetida a uma coluna de cromatografia preparada com DEAE celulose (DEAE-sephacel) e equilibrada com PBS $1 / 2$ concentrado, pH 7,8. Quinze frações de $1 \mathrm{ml}$ cada foram coletadas e determinada a absorbância a $280 \mathrm{~nm}$, em espectrofotômetro de luz ultravioleta. A concentração foi calculada admitindo-se que para absorbância de 1,4 corresponde a $1 \mathrm{mg}$ de lgG por $\mathrm{ml}$ (Almeida, 1995b). A IgG purificada foi conservada em frascos de vidro a $4^{\circ} \mathrm{C}$.

\subsection{DAS-ELISA indireto}

\subsubsection{Padronização do método}

A técnica de DAS-ELISA indireto, em resumo, consiste da utilização de anticorpos produzidos em dois animais (ex.: coelho e galinha) para a reação sorológica. $O$ anticorpo produzido pelo primeiro animal captura o antígeno, enquanto que aquele produzido pelo segundo animal completa o sanduíche. A reação sorológica é então detectada através da reação enzimática, utilizandose anticorpo apropriado que reage com a imunoglobulina do segundo animal e conjugado com uma enzima (Van Regenmortel, 1982 e Van Regenmortel \& Dubs, 1993).

Para a utilização dessa técnica, no entanto, é necessário estabelecer a melhor seqüência dos dois anticorpos, bem como as diluições mais adequadas dos mesmos. Para tal foram realizados testes preliminares utilizando-se diferentes concentrações de IgG produzida em coelho para a captura do antígeno e de lgY obtida em galinha para completar a reação sorológica, e vice-versa. Esses testes seguiram o seguinte procedimento: Inicialmente preparou-se a IgG de coelho, nas concentrações de 1,0;5,0;10,0 e 20,0 $\mu \mathrm{g} / \mathrm{ml}$, 
diluída em tampão carbonato $\left(0,015 \mathrm{M} \mathrm{Na}_{2} \mathrm{CO}_{3}, 0,035 \mathrm{M} \mathrm{NaHCO}_{3}, \mathrm{pH} 9,6\right)$. Cada diluição foi colocada em 2 pocinhos da placa de ELISA, na proporção de $100 \mu \mathrm{l}$ por pocinho, seguindo o esquema da Figura 1. A placa foi incubada por $1,5 \mathrm{~h}$ a $37^{\circ} \mathrm{C}$. Em seguida a placa foi lavada 3 vezes consecutivas com PBSTween $\left(0,0015 \mathrm{M} \mathrm{KH}_{2} \mathrm{PO}_{4}, 0,14 \mathrm{M} \mathrm{NaCl}, 0,004 \mathrm{M} \mathrm{Na}_{2} \mathrm{HPO}_{4}, 0,003 \mathrm{KCl}, \mathrm{pH} \mathrm{7,4+}\right.$ $0,5 \mathrm{ml}$ Tween 20/l). Extratos de plantas de maracujazeiro infectado e sadio, diluídos 1:20 em PBS-Tween, foram adicionados na placa, na proporção de $100 \mu \mathrm{l}$ por pocinho. Depois de um período de incubação de $1,5 \mathrm{~h}$ a $37^{\circ} \mathrm{C}$, a placa foi lavada 3 vezes com PBS-Tween. Preparou-se as suspensões de IgY de galinha, nas concentrações de 1,0; 5,0 e 10,0 $\mu \mathrm{g} / \mathrm{ml}$, diluída em PBS-Tween com 1\% BSA (Bovine serum albumin). Cada diluição foi colocada em 3 pocinhos da placa de ELISA, na proporção de $100 \mu \mathrm{l}$ por pocinho, seguindo o esquema da Figura 1. Incubou-se a placa por $1,5 \mathrm{~h}$ a $37^{\circ} \mathrm{C}$. A seguir a placa foi lavada 3 vezes como anteriormente. Colocou-se $100 \mu \mathrm{l}$ de IgG de cabra contra IgY de galinha, conjugada com fosfatase alcalina (SIGMA A-9171), diluída 1:10.000 em PBS-Tween contendo $2 \%$ polyvinylpyrrolidone. A placa foi novamente incubada por $1,5 \mathrm{~h}, \mathrm{a} 37^{\circ} \mathrm{C}$. Depois de lavada como anteriormente, colocou-se $100 \mu \mathrm{l}$ de $\rho$-fosfato de nitrofenil (SIGMA N-9389) diluído em tampão dietanolamina $\mathrm{pH} 9,8(0,6 \mathrm{mg} / \mathrm{ml})$, por pocinho. Incubou-se à temperatura ambiente, no escuro, onde ocorreu a reação enzimática (30 a 60 minutos). A absorbância de cada um dos pocinhos foi medida no leitor de ELISA, da marca Metertech $\Sigma$ 960, utilizando-se filtro de $405 \mathrm{~nm}$. (Van Regenmortel \& Dubs, 1993)

O mesmo teste foi realizado invertendo-se as posições das imunoglobulinas (Figura 1). As diluições das imunoglobulinas foram as mesmas mencionadas anteriormente. Todas as etapas foram executadas conforme descrito acima, exceto que nesse caso foi utilizada IgG de cabra contra IgG de coelho, conjugada com fosfatase alcalina (SIGMA A-3687), diluída 1:32.000 em PBS-Tween contendo $2 \%$ polyvinylpyrrolidone. 
$\lg \mathrm{G}$ coelho $(\mu \mathrm{g} / \mathrm{ml})$

\begin{tabular}{|c|c|c|c|c|c|c|}
\hline & 01 & 05 & 10 & 20 & & \\
\hline 7 & PWV & PWV & PW & PWV & 01 & \\
\hline 6 & PWV & PWV & PWV & PWV & 05 & \\
\hline 5 & PWV & PW & PW & PWV & 10 & \\
\hline 4 & Sadia & Sadia & Sadia & Sadia & 01 & IgY galinha $(\mu \mathrm{g} / \mathrm{ml})$ \\
\hline 3 & Sadia & Sadia & Sadia & Sadia & 05 & \\
\hline 2 & Sadia & Sadia & Sadia & Sadia & 10 & \\
\hline 1 & Água & Água & - & - & & \\
\hline
\end{tabular}

Figura 01. Diagrama da distribuição e concentrações das $\operatorname{lgg}$ e $\lg Y$ e distribuição das amostras infectadas com o PWW e sadias, em uma parte da placa de ELISA. Cada retângulo representa dois pocinhos da placa. Água foi acrescentada no momento de zerar o leitor de ELISA.

\subsubsection{Para fins de diagnóstico}

Testes para avaliar a sensibilidade da técnica de DAS-ELISA indireto para fins de diagnóstico foram realizados da seguinte maneira: inicialmente foram preparadas suspensões do PWV purificado, nas concentrações de 10 , $20,40,80,160,320,640,1.280,2.560$ e $5.120 \mathrm{ng} / \mathrm{ml}$. Essa diluições foram preparadas em extrato de plantas de maracujazeiro sadio, diluído 1:500, em 
tampão PBS-Tween. Como controle negativo foi utilizado o mesmo extrato de planta sadia na diluição de 1:500 em PBS-Tween. Cada uma das concentrações do vírus, bem como o controle negativo, foi distribuída ao acaso em 2 pocinhos da placa de ELISA. Todas as etapas do teste de DAS-ELISA indireto foram executadas conforme apresentadas no item 3.7.1., utilizando-se a lgG, na concentração de $10 \mu \mathrm{g} / \mathrm{ml}$, para a captura do antígeno e a lgY, na concentração de $1 \mu \mathrm{g} / \mathrm{ml}$, para completar o sanduíche da reação sorológica. O teste foi repetido 2 vezes.

A reação foi considerada positiva quando o valor médio da absorbância a $405 \mathrm{~nm}$ excedia em 2 vezes o valor médio da absorbância do extrato da planta sadia (Sutula et al., 1986).

\subsubsection{Para fins quantitativos}

Para os testes de estimativa da concentração do PWW foram utilizadas plantas infectadas de maracujazeiro, $P$. vulgaris L. (cv. Black Turtle 2) e Crotalaria juncea. Grupos de plantas dessas espécies foram inoculadas mecanicamente com os três isolados do PWV, separadamente. Quinze dias após a inoculação foram feitas avaliações dos sintomas, utilizando a escala de notas descrita anteriormente.

As amostras para os estudos quantitativos do PWV foram coletadas 15 dias após a inoculação, da seguinte maneira: primeiramente foram escolhidas as 3 folhas expandidas próximas do ponteiro das plantas. De cada folha foram coletados 3 discos, de $1 \mathrm{~cm}$ de diâmetro, num total de 9 discos por planta. Os discos foliares coletados de cada planta foram macerados em tampão PBS sem tween, numa diluição de $1: 10$ e armazenados a $-20^{\circ} \mathrm{C}$. Todas as amostras coletadas de cada espécie foram avaliadas conjuntamente através do DAS- 
ELISA indireto, conforme descrito em 3.7.1., e utilizando-se a seqüência e as concentrações de imunoglobulinas descritas em 3.7.2. As amostras foram descongeladas e diluídas 1:500 em PBS-Tween. Essa diluição foi escolhida com base em testes preliminares que resultaram em valores de absorbância situados na região das concentrações conhecidas do vírus. Como padrão de concentração do PWW foram utilizadas as seguintes diluições do vírus purificado: $10,20,40,80,160,320,640,1280,2560$ e $5120 \mathrm{ng} / \mathrm{ml}$. Todas as amostras bem como os padrões de concentrações conhecidas do PWV foram testados em pocinhos duplicados. Os valores de absorbância a $405 \mathrm{~nm}$ obtidos nas concentrações padrões foram submetidos a uma análise de regressão linear, cuja equação foi utilizada para estimar a concentração do PWV de acordo com os valores médios de absorbância obtidos para as amostras das plantas-teste.

\subsection{Análise de correlação entre notas de sintomas e concentração do PWV}

A correlação entre notas de sintomas e as concentrações do PWV nos tecidos das plantas infectadas foi analisada utilizando-se o programa Statistical Analysis System V. 6.08 (SAS Institute, 1993). A significância da correlação obtida foi avaliada aplicando-se o teste $\mathbf{t}$ para coeficientes de correlação, segundo Gomes (1990). 


\section{RESULTADOS}

\subsection{Purificação do PWV}

Durante a realização desse trabalho foram feitas 3 purificações do PWV a partir de folhas infectadas de feijão-de-porco. A metodologia utilizada mostrou-se bastante eficiente, permitindo em geral a obtenção de preparações purificadas com concentrações finais que variaram de 1,20 a 1,88 mg de vírus por $100 \mathrm{~g}$ de tecido infectado. As preparaçōes virais obtidas apresentaram espectros de absorção com um máximo em 260 nm e um mínimo em $245 \mathrm{~nm}$ (Figura 2). As razões entre as absorções nos comprimentos de onda 260 e 280 $\mathrm{nm}\left(\mathrm{A}_{260} / \mathrm{A}_{280}\right)$ e máxima e mínima $\left(A_{\max } / A_{\min }\right)$ foram de 1,29 e 1,15 , respectivamente.

Amostras da suspensão do vírus purificado foram observadas em microscópio eletrônico de transmissão, sendo visualizada uma grande quantidade de partículas do tipo potyvirus (Figura 3).

O PWW purificado foi inoculado em plantas sadias de maracujazeiro, de feijão-de-porco e de $C$. amaranticolor, para avaliar a infectividade das partículas. As plantas de maracujazeiro e de feijão-de-porco apresentaram sintomas de mosaico típico, enquanto que as de $C$. amaranticolor mostraram lesões locais cloróticas, cinco dias após a inoculação. 


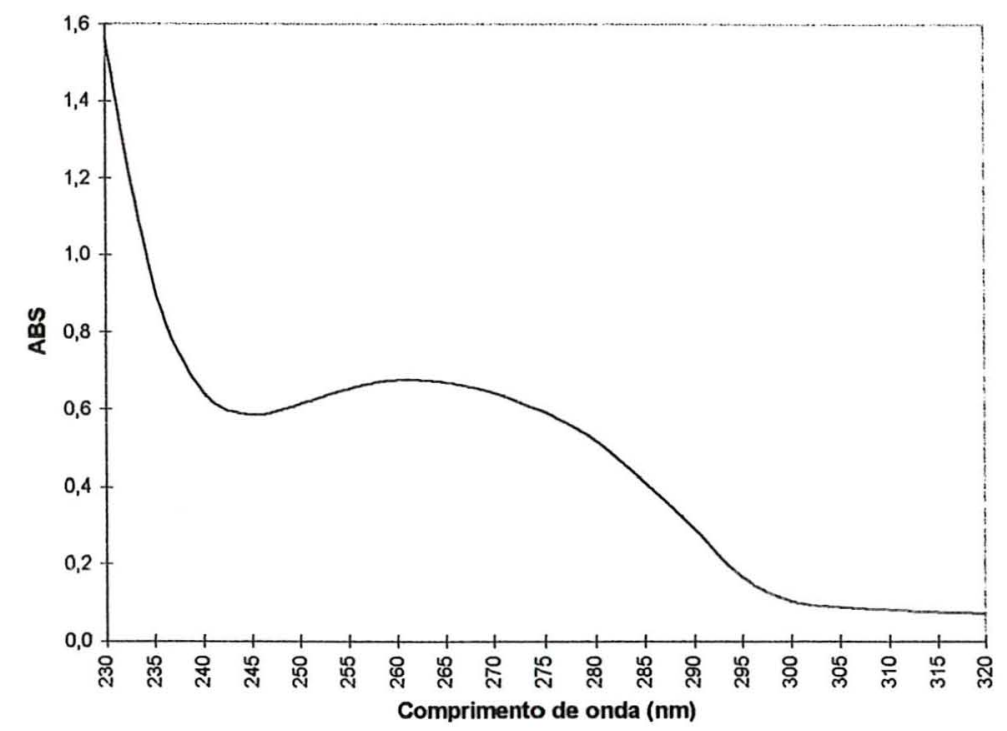

Figura 2. Espectro de absorção ultravioleta $(230-320 \mathrm{~nm})$ da preparação purificada do PWV, obtida a partir de plantas de feijão-de-porco infectadas.

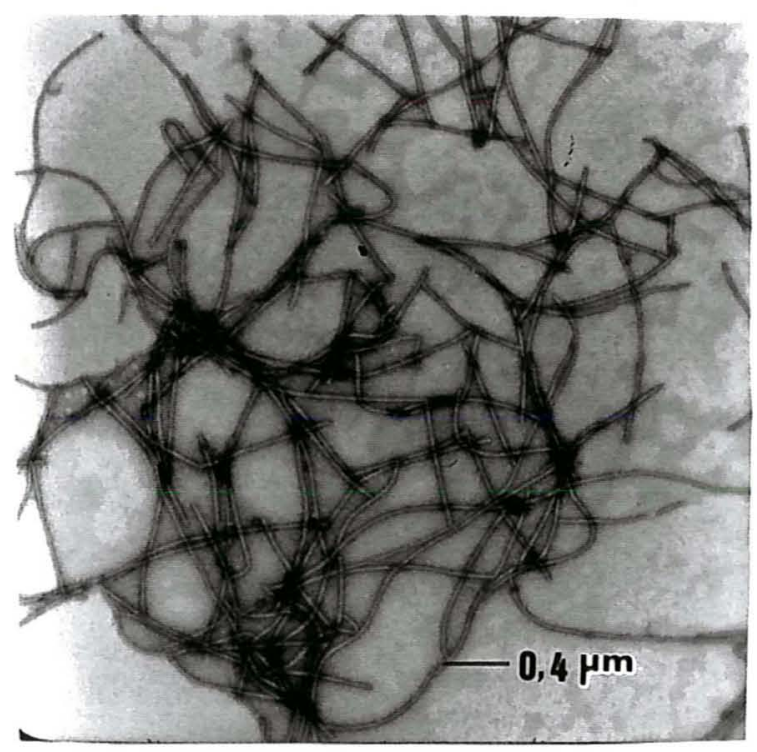

Figura 3. Micrografia eletrônica de uma preparação purificada do PWV contrastada negativamente com acetato de uranila $1 \%$, contendo grupos de partículas alongadas típicas de potyvirus. Aumento de 20.000 vezes. 


\subsection{Obtenção de antissoros para o PWV}

Para a obtenção de antissoro a partir de gemas de ovos de galinha imunizada com o PWW purificado foram utilizadas 2 gemas. A concentração de Imunoglobulina $Y$ ( $\operatorname{lgY}$ ) determinada pela absorbância em espectrofotômetro, a $280 \mathrm{~nm}$, foi de $6,25 \mathrm{mg} / \mathrm{ml}$ de gema.

Em coelho, primeiramente foi obtido um antissoro bruto, dez dias após a última imunização. No processo de purificação da Imunoglobulina $G$ ( $\operatorname{lgG}$ ), através da precipitação com solução saturada de sulfato de amônio e posterior passagem por coluna de cromatografia de troca iônica, foram coletadas 15 frações de $1 \mathrm{ml}$. Leituras de absorbância em espectrofotômetro, a $280 \mathrm{~nm}$, indicaram a presença de concentrações variáveis de IgG nas frações de número 4 a 12. A IgG presente nessas frações foi concentrada, através da precipitação com sulfato de amônio saturado. O precipitado obtido foi dissolvido em $2 \mathrm{ml}$ de PBS $1 / 2$ concentrado e dialisado. A concentração final da IgG determinada em espectrofotômetro, a $280 \mathrm{~nm}$, foi de $1,86 \mathrm{mg} / \mathrm{ml}$.

\subsection{Padronização do teste de DAS-ELISA indireto}

Foram realizados 2 testes independentes de DAS-ELISA indireto para estabelecer a melhor seqüência dos anticorpos bem como as melhores diluições dos mesmos. Na Figura 4 são apresentados os valores médios de absorbância obtidos nos testes em que a lgG foi utilizada para a captura do antígeno (PWV) e a IgY foi usada para completar o sanduiche da reação sorológica. As absorbâncias obtidas com o extrato de planta sadia (controle) variaram de 0,028 a 0,174 , enquanto que para o extrato de planta infectada as 
leituras ficaram entre 0,825 e 2,418. A menor diferença entre o dobro da absorbância do extrato de planta sadia e infectada foi de aproximadamente 9,0 vezes, quando utilizou-se $1 \mu \mathrm{g}$ de $\mathrm{IgG}$ e $10 \mu \mathrm{g}$ de $\mathrm{IgY}$. A maior diferença foi de 55,4 vezes, quando foi utilizada $10 \mu \mathrm{g}$ de $\lg$ e $1 \mu \mathrm{g}$ de $\lg Y$. Notou-se ainda que à medida que se aumenta a concentração da $\lg Y$ de 1 para $10 \mathrm{ng} / \mathrm{ml}$ há uma tendência de aumento na reação com extrato de planta sadia. As menores reações no geral foram obtidas quando utilizou-se $1 \mathrm{ng} / \mathrm{ml}$ dessa imunoglobulina.

Na Figura 5 são apresentados os valores médios de absorbância obtidos nos testes em que as imunoglobulinas foram utilizadas de forma invertida à descrita acima, porém nas mesmas concentrações. As absorbâncias obtidas com o extrato de planta sadia (controle) variaram de 0,047 a 0,187 , sendo ligeiramente superiores as obtidas no caso anterior. As absorbâncias para o extrato de planta infectada ficaram entre 0,401 e 1,190, representando menos da metade daquelas obtidas quando as imunoglobulinas foram usadas de forma invertida. A menor diferença entre o dobro da absorbância do extrato de planta sadia e infectada foi de 5,9 vezes, quando utilizou-se $10 \mu \mathrm{g}$ de lgY e 20 $\mu \mathrm{g}$ de IgG, enquanto que a maior diferença encontrada foi de aproximadamente 12 vezes, quando foi utilizada $1 \mu \mathrm{g}$ de $\lg Y$ e $5 \mu \mathrm{g}$ de $\mathrm{IgG}$.

Considerando-se os menores valores de absorbância obtidos com o extrato de planta sadia (controle) e as maiores diferenças entre o dobro dessas e os valores obtidos com extrato de planta infectada com o PWV, escolheu-se como padrão para o DAS-ELISA indireto a utilização de $10 \mu \mathrm{g} / \mathrm{ml}$ de IgG para a captura do vírus, seguida pela lgY, na concentração de $1 \mu \mathrm{g} / \mathrm{ml}$. 


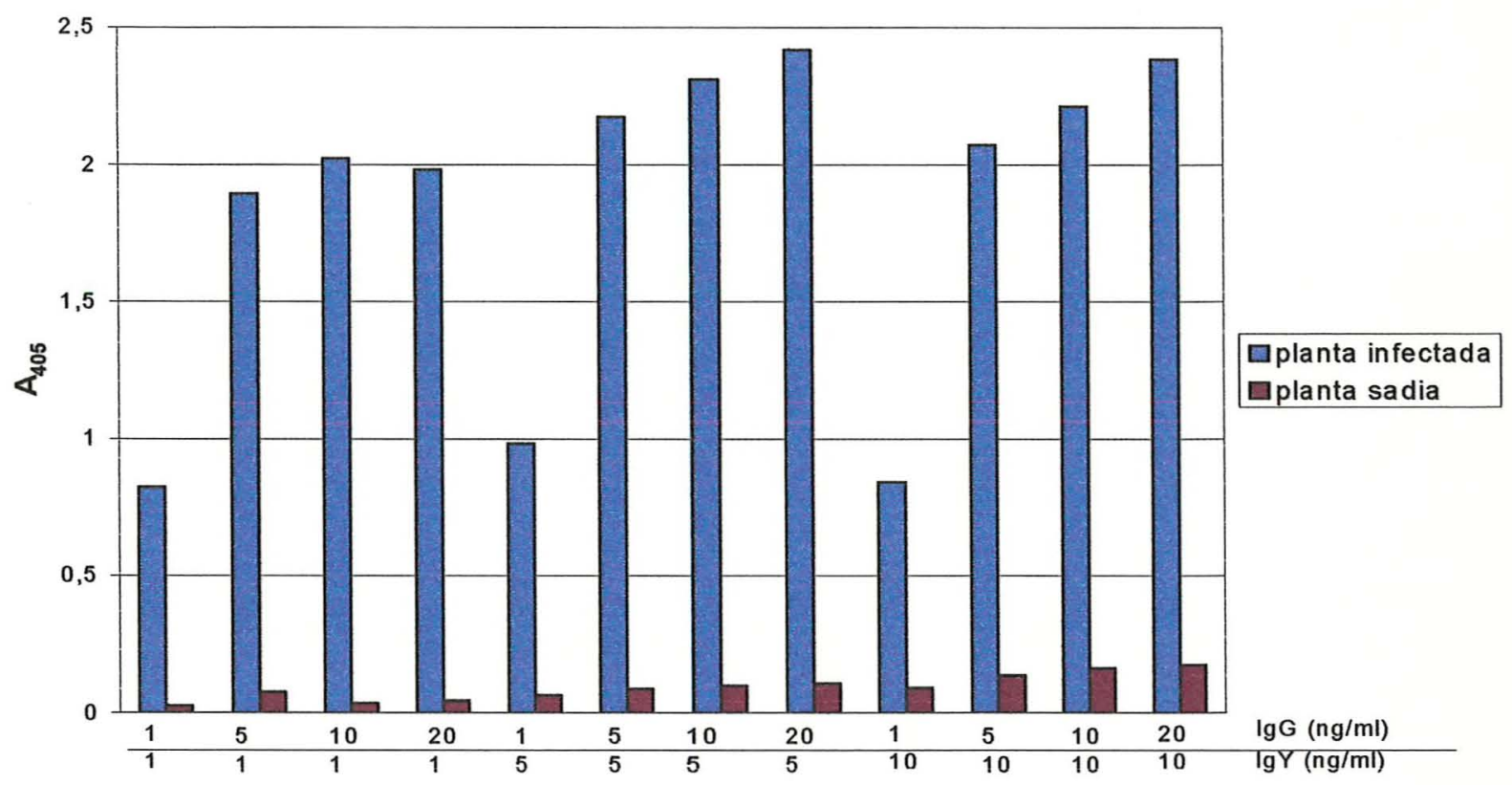

Figura 4. Valores médios de absorbância $\left(A_{405}\right)$ obtidos na padronização do teste de DAS-ELISA indireto, utilizando diferentes concentrações de IgG e IgY, respectivamente, para a captura do PWV e para completar o sanduíche da reação sorológica. 


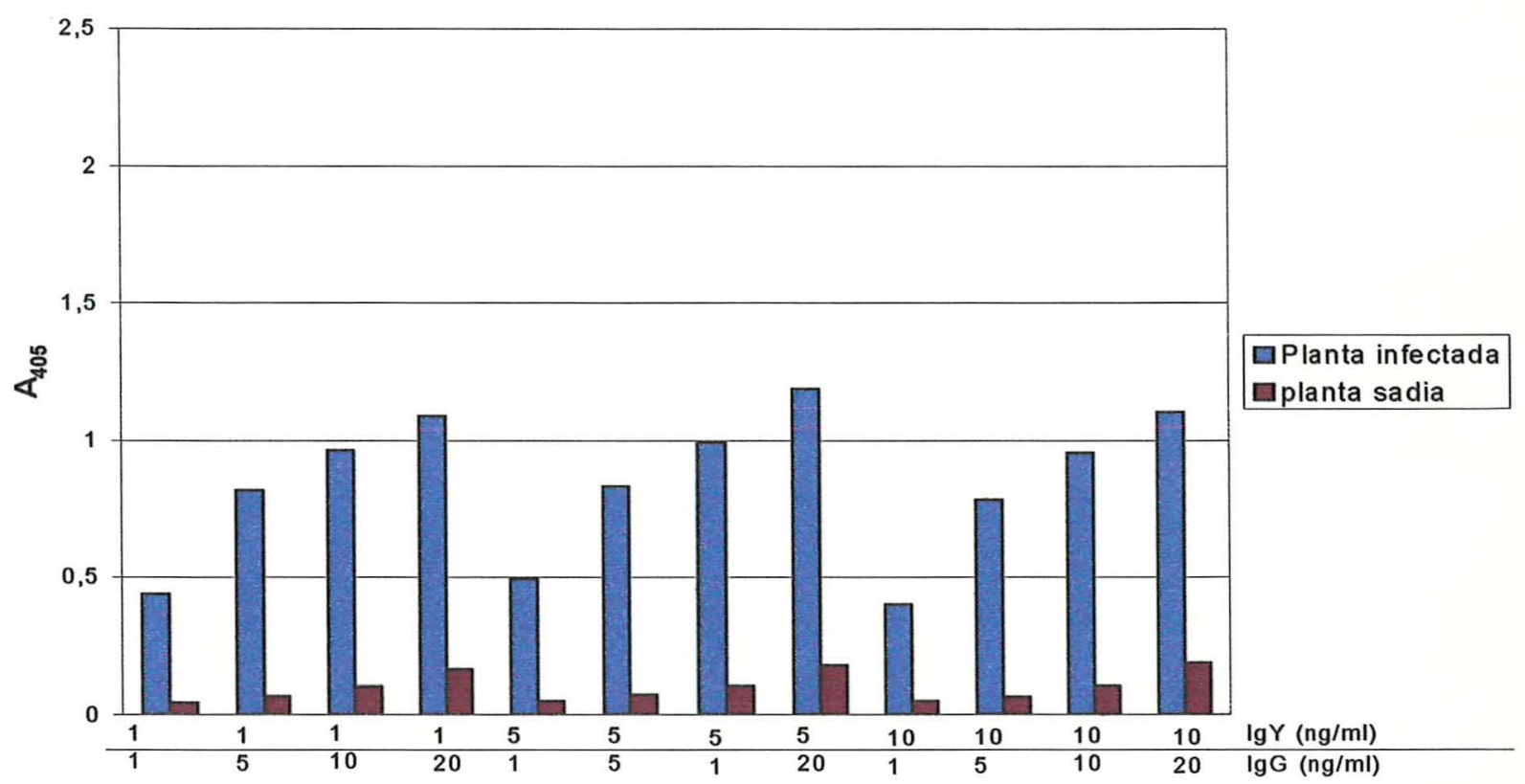

Figura 5. Valores médios de absorbância $\left(A_{405}\right)$ obtidos na padronização do teste de DAS-ELISA indireto, utilizando diferentes concentrações de IgY e IgG, respectivamente, para a captura do PWV e para completar o sanduíche da reação sorológica. 


\subsection{Sensibilidade do DAS-ELISA indireto para a detecção do PWV}

Os resultados de 2 experimentos independentes, para a avaliação da sensibilidade do teste de DAS-ELISA indireto para a detecção do PWV estão apresentados no apêndice 1 e representados na Figura 6 . 0 teste foi altamente sensivel, permitindo a detecção desde 5.120 até $20 \mathrm{ng} / \mathrm{ml}$ do PWW purificado.

Embora a absorbância média para a concentração de $10 \mathrm{ng} / \mathrm{ml}$ tenha sido de 0,184 , esse valor ficou abaixo de duas vezes a média da absorbância do extrato de planta sadia $(0,2)$, que foi previamente estabelecido como padrão para separar as reações consideradas positivas das negativas.

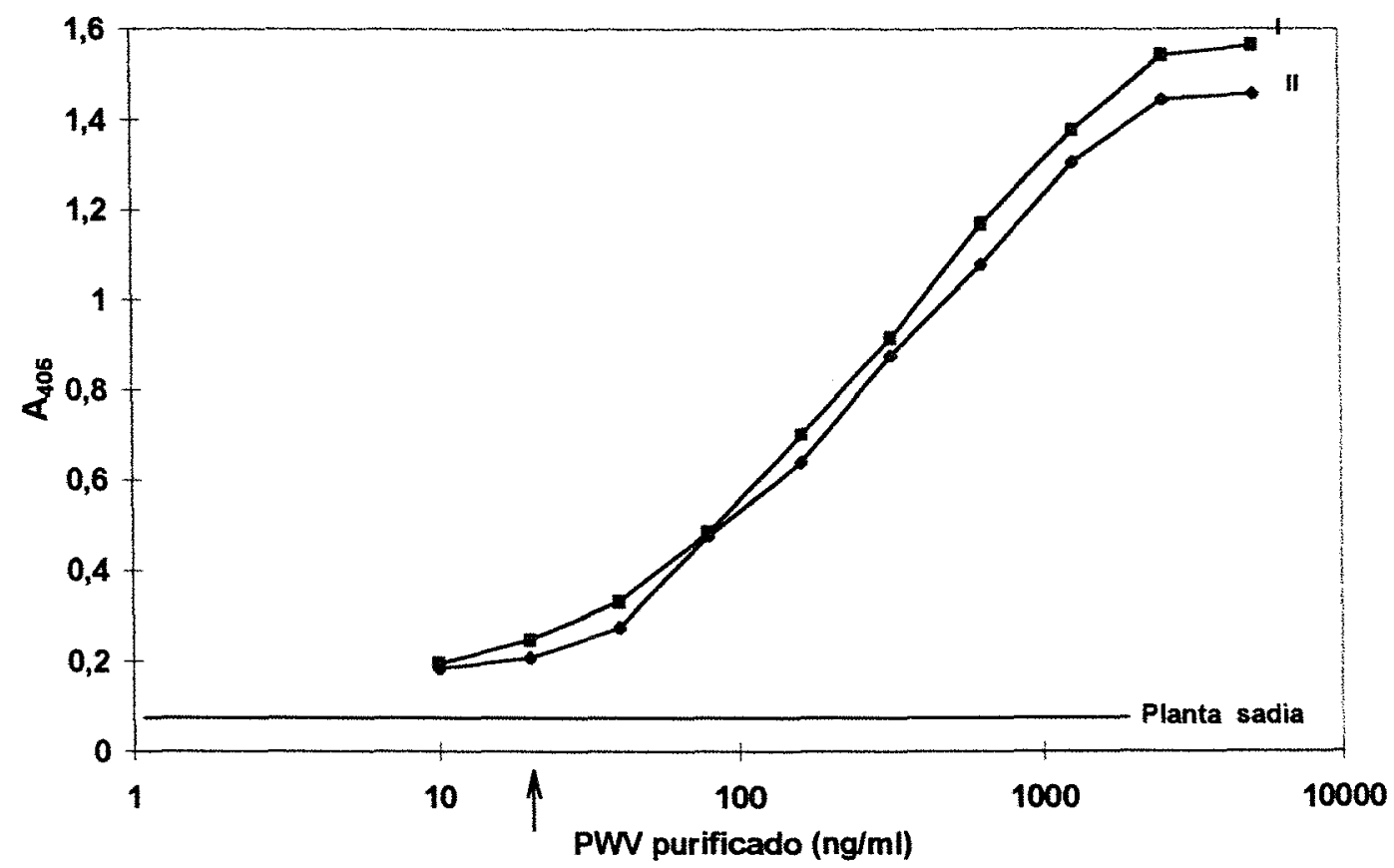

Figura 6. Valores de absorbância $\left(A_{405}\right)$ obtidos em dois testes (I e II) para avaliar a sensibilidade do DAS-ELISA indireto para a detecção de diferentes concentrações do PWV. Flecha indica concentração de 20 $\mathrm{ng} / \mathrm{ml}$. 
4.5 Obtenção da equação de regressão linear utilizada na quantificação do PWV

As estimativas da concentração do PWW em tecidos de plantas infectadas foram feitas utilizando-se equações de regressão linear, obtidas com os valores das concentraçōes conhecidas do vírus purificado e as respectivas absorbâncias a $405 \mathrm{~nm}$.

No geral, os valores de absorbância obtidos com as concentrações préestabelecidas variaram de 0,196 a 1,564, e foram semelhantes aos apresentados na Figura 6. Para estabelecer a equação de regressão linear, utilizando-se como modelo os valores de uma das curvas da Figura 6, foram escolhidos os pontos da curva onde há uma relação diretamente proporcional entre a concentração do PWV e a absorbância a $405 \mathrm{~nm}$, conforme ilustrado na Figura 7. Neste caso a linearidade encontra-se na faixa de 40 a $2.560 \mathrm{ng}$ de vírus/ml. A equação de regressão para a curva dessa figura é: $Y=0,2886 \mathrm{LN}(X)$ 0,7938 .

A utilização da equação, para estimar a concentração do PWV em amostra de tecido de planta infectada, é feita substituindo-se a incógnita ( $Y$ ) pelo valor da média da absorbância obtida para a amostra. A concentração obtida é corrigida em função da diluição da amostra. 
29

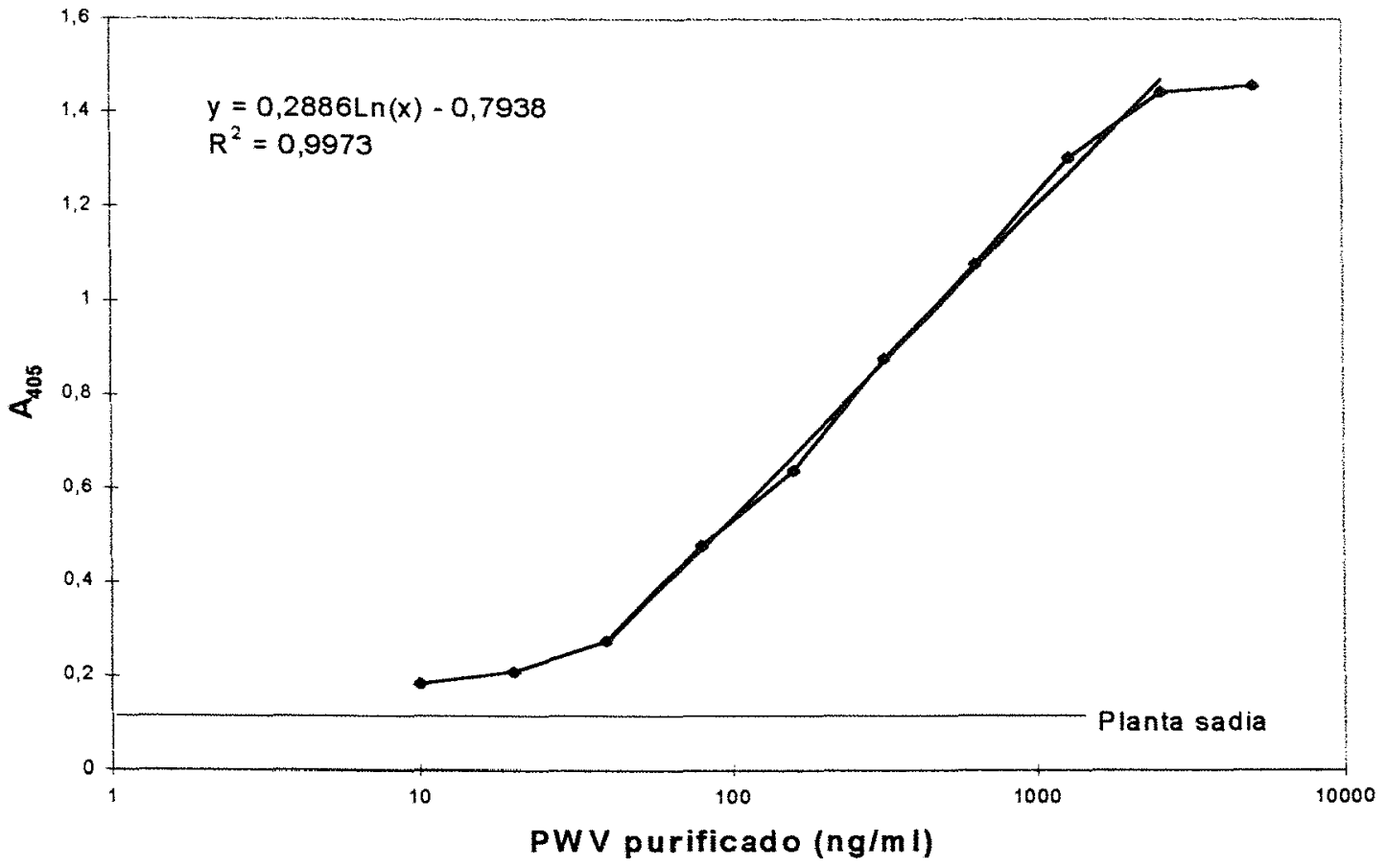

Figura 7. Relação de linearidade entre valores de absorbância $\left(A_{405}\right)$ e concentrações conhecidas do PWV purificado. 


\subsection{Quantificação do PWV através do DAS-ELISA indireto}

Os resultados das estimativas de concentração do PWV através do DAS-ELISA indireto e as respectivas notas de sintomas em diferentes plantas de Passiflora edulis f. flavicarpa, $P$. giberti e $P$. cincinnata, inoculadas com 0 isolado do PWV de Vera Cruz (SP), estão representados na Figura 8. Os valores individuais e médios de absorbância para cada planta avaliada estão no Apêndice 2.

A concentração do PWV nos tecidos das oito plantas de cada espécie testada variou de 71,0 a $1.232,5 \mu \mathrm{g} / \mathrm{g}$ tecido em $P$. e. f. flavicarpa, 45,0 a 669,5 $\mu \mathrm{g} / \mathrm{g}$ de tecido em $P$. giberti e de 25,0 a $1.820,0 \mu \mathrm{g} / \mathrm{g}$ de tecido em $P$. cincinnata. Nas três espécies, a maioria das plantas apresentou uma intensificação de sintomas relacionada com a concentração do PWV nos tecidos. Análise de correlação entre notas de sintomas e concentração do vírus indicou que, com exceção de $P$. e. f. flavicarpa, houve correlação positiva e significativa para as plantas de $P$. giberti e de $P$. cincinnata (Quadro 1).

Nas Figuras 9 a 11 estão representados os resultados das estimativas de concentração do PWV e das respectivas notas de sintomas em diferentes plantas de $P$. e. f. flavicarpa, Crotalaria juncea e Phaseolus vulgaris cv. Black Turtle 2, respectivamente, inoculadas com os isolados do PWV de Vera Cruz (SP), Brasília e Minas Gerais. Grupos de 6 plantas, de cada espécie, foram inoculados com os três isolados do vírus, separadamente. Os valores de absorbância a $405 \mathrm{~nm}$ obtidos para cada planta testada de cada uma das espécies se encontram no Apêndice 3.

Observa-se na Figura 9 que no geral as concentrações do PWV em plantas de P. e. f. flavicarpa, independentemente do isolado do vírus inoculado, variaram de 61,14 a $322,86 \mu \mathrm{g} / \mathrm{g}$ de tecido. No caso das plantas inoculadas com o isolado Vera Cruz, observa-se que a maior concentração do vírus 
encontrada ficou bem abaixo das maiores concentrações obtidas em avaliação anterior (Figura 8). A análise de correlação entre essas variáveis foi positiva e significativa para as plantas de $P$. e. f. flavicarpa (Quadro 1).

A concentração estimada do PWV em plantas de C. juncea, independentemente dos isolados do PWW inoculado, variou de 43,8 a 99,1 $\mu \mathrm{g} / \mathrm{g}$ de tecido (Figura 10), enquanto que em $P$. vulgaris cv. Black Turtle 2, a variação foi de 48,4 a $84,6 \mu \mathrm{g} / \mathrm{g}$ de tecido (Figura 11). Foi encontrada correlação positiva e significativa também entre as notas de sintomas e a concentração do PWV em plantas de $C$. juncea (Quadro 1). Os dados relativos às plantas de $P$. vulgaris $\mathrm{cv}$. Black Turtle 2 não foram correlacionados, pois todas as plantas receberam a mesma nota de sintomas. As figuras 10 e 11 mostraram ainda que a concentração média do PWV em plantas da família Leguminosae foi menor do que em plantas das três espécies do gênero Passiflora estudadas (Figuras 8 e 9). 


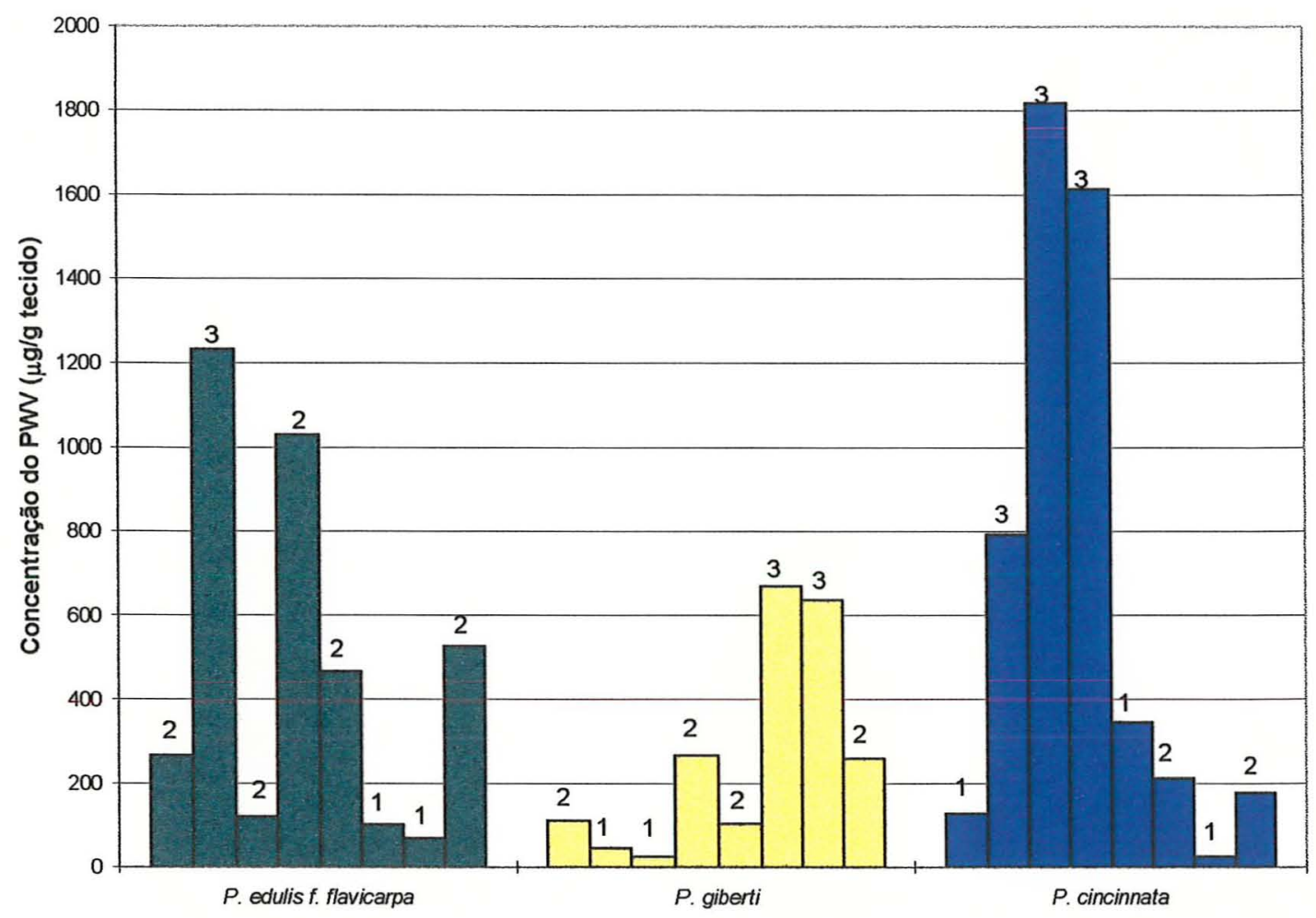

Figura 8. Concentração estimada do PWV em plantas de 3 espécies de maracujazeiro inoculadas com o isolado de Vera Cruz (VC), com respectivas notas de sintomas $(1=$ sem sintomas aparente de mosaico; 2= mosaico leve e $3=$ mosaico severo, deformações foliares e bolhas). 


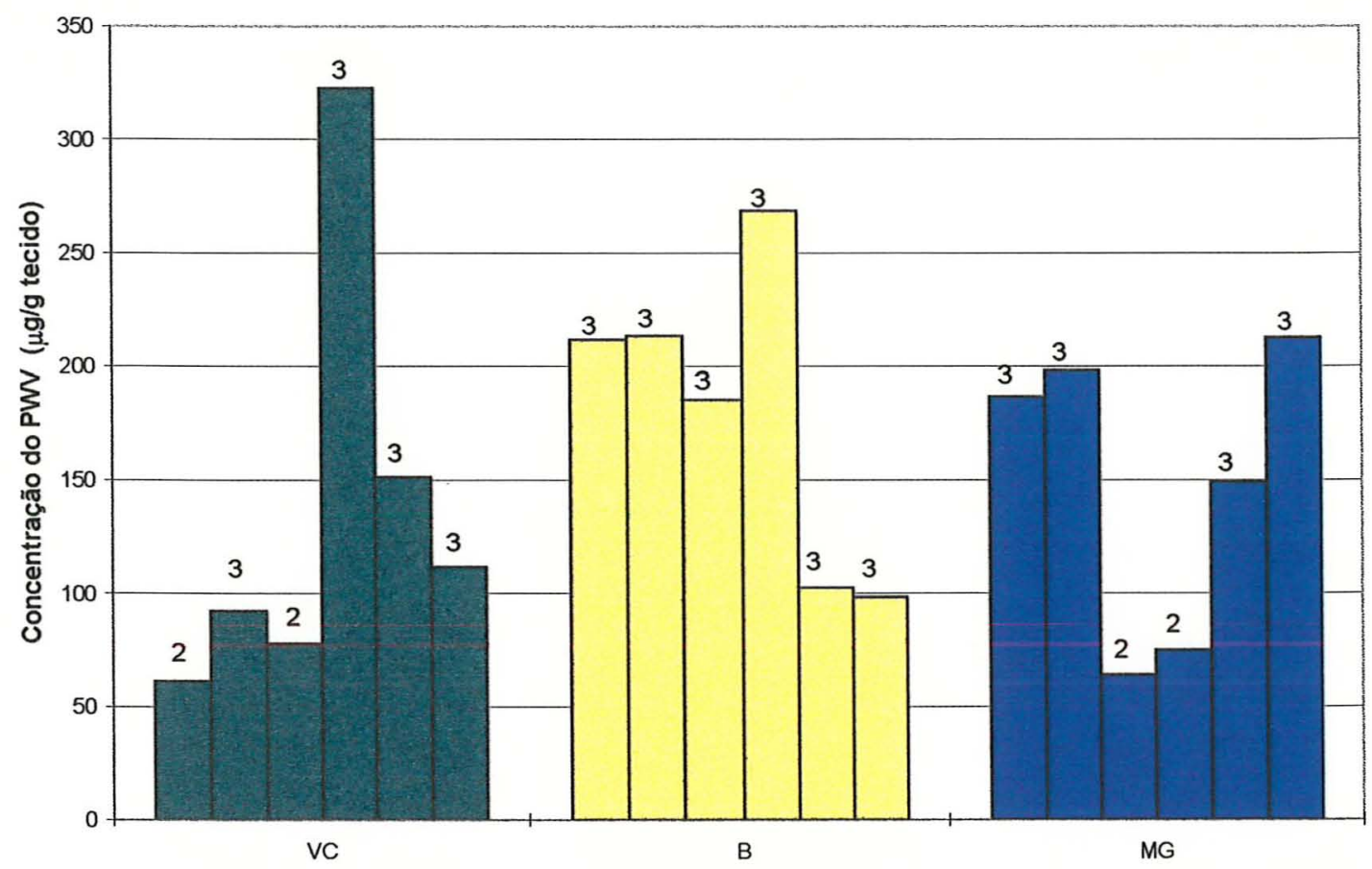

Figura 9. Concentração estimada do PWV em plantas de $P$. edulis f. flavicarpa, inoculadas com os isolados de Vera Cruz (VC), Brasília (B) e Minas Gerais (MG), com respectivas notas de sintomas ( $1=$ sem sintomas aparente de mosaico; $2=$ mosaico leve e $3=$ mosaico severo, deformações foliares e bolhas). 


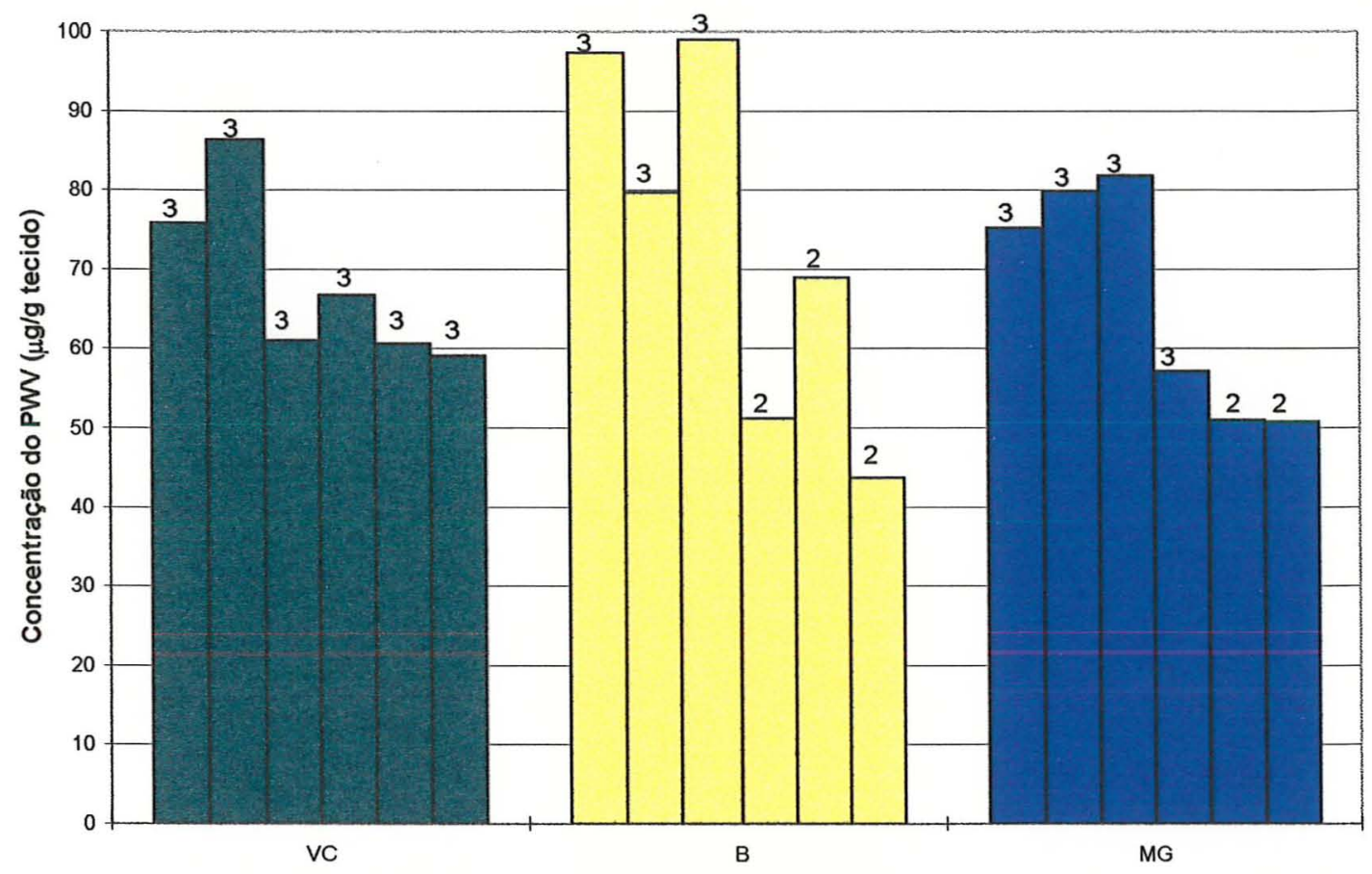

Figura 10. Concentração estimada do PWV em plantas de C. juncea, inoculadas com os isolados de Vera Cruz (VC), Brasília (B) e Minas Gerais (MG), com respectivas notas de sintomas (1= sem sintomas aparente de mosaico; $2=$ mosaico leve e $3=$ mosaico severo, deformações foliares e bolhas). 


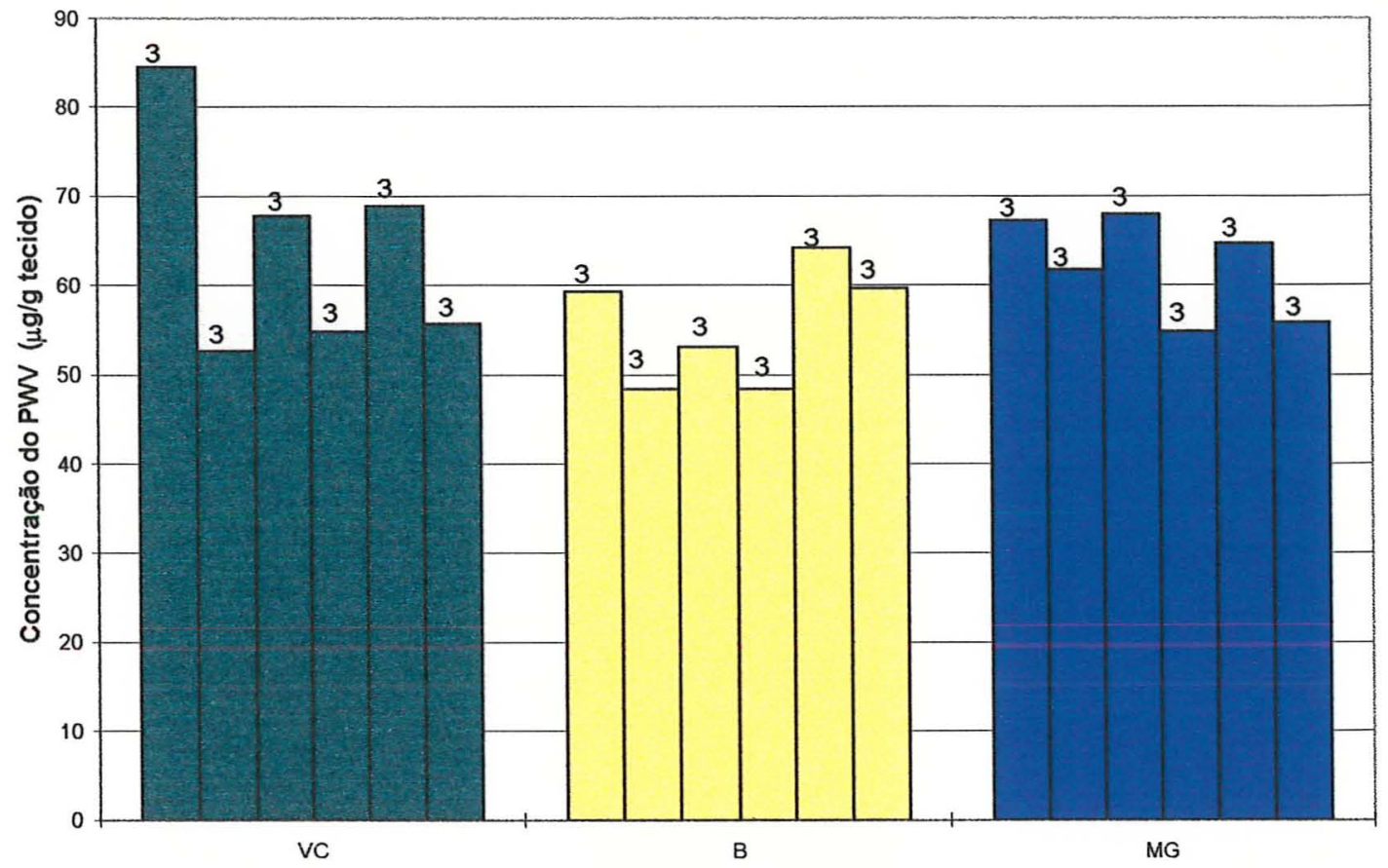

Figura 11. Concentração estimada do PWV em plantas de $P$. vulgaris cv. Black Turtle 2, inoculadas com os isolados de Vera Cruz (VC), Brasília (B) e Minas Gerais (MG), com respectivas notas de sintomas (1= sem sintomas aparente de mosaico; $2=$ mosaico leve e $3=$ mosaico severo, deformações foliares e bolhas). 
Quadro 1. Coeficientes de correlação entre concentrações do PWV nos tecidos e notas de sintomas para as plantas de diferentes espécies infectadas com os isolados de Vera Cruz (VC), Brasília (B) e Minas Gerais (MG).

\begin{tabular}{lcc}
\hline \multicolumn{1}{c}{ Espécies } & \multicolumn{2}{c}{ Coeficientes de correlação } \\
\hline & $\mathrm{VC}$ & $\mathrm{VC}+\mathrm{B}+\mathrm{MG}^{1}$ \\
\cline { 2 - 3 }$P$. edulis f. flavicarpa & $0,678^{\text {n.s. }}$ & $0,623^{\star \star}$ \\
$P$. giberti & $0,914^{\star \star}$ & - \\
P. cincinnata & $0,815^{*}$ & - \\
C. juncea & - & $0,631^{\star \star}$ \\
\hline
\end{tabular}

n.S. = não significativo, ${ }^{*}=$ significativo a $5 \%,{ }^{* \star}=$ significativo a $1 \%$

1 Plantas inoculadas com os isolados VC, B e MG foram analisadas conjuntamente. 


\section{DISCUSSÃO}

\subsection{Purificação do PWV}

A utilização do protocolo para purificação de alguns potyvirus, desenvolvido por Marinho \& Kitajima (1989), com algumas modificações, permitiu a obtenção de purificados do PWV a partir de plantas de feijão-deporco, com niveis aparentemente adequados de pureza (Figura 3). As concentrações obtidas nas diferentes purificações foram semelhantes à conseguida por Bezerra et al. (1995), que purificaram o PWV a partir de folhas de Macroptilium lathyroides (Leguminosae) e obtiveram uma concentração final máxima de $1,82 \mathrm{mg}$ de vírus por $100 \mathrm{~g}$ de tecido. O resultado obtido na purificação do PWV também está de acordo com o relatado para outros potyvirus (Noordam, 1973).

De acordo com Matthews (1991), a quantidade de virus que pode ser extraída de um tecido vegetal infectado pode variar de 0,04 a $400 \mathrm{mg} / 100 \mathrm{~g}$ de tecido fresco. Isto porque há diversos fatores que podem afetar a qualidade e a quantidade do vírus purificado, tais como estirpe do vírus, planta na qual o vírus foi multiplicado, fatores ambientais, agentes físicos e químicos utilizados no processo de purificação, etc. Nesse trabalho, as plantas de feijão-de-porco mostraram-se satisfatórias para a multiplicação e posterior purificação do PWV. São de fácil obtenção, desenvolvem-se rapidamente e produzem grande 
quantidade de massa verde em curto espaço de tempo. Além disso, aparentemente não indicaram a presença de fatores adversos que pudessem dificultar a obtenção de concentrações adequadas de vírus purificado. O procedimento utilizado na purificação desse vírus também não parece ter afetado a infectividade do ácido nucléico, uma vez que as plantas de maracujazeiro, feijão-de-porco e C. amaranticolor inoculadas com uma suspensão do vírus purificado foram facilmente infectadas. Também não parece ter afetado a imunogenicidade da proteína da capa protéica, uma vez que foram produzidos anticorpos de boa qualidade, conforme será discutido a seguir.

\subsection{Produção de antissoros para o PWV}

O PWW purificado mostrou-se altamente imunogênico quando injetado em coelho da raça Nova Zelândia e em galinha da Linhagem IPEG. O procedimento de 6 injeções intramusculares em coelho e de 3 em galinha, a intervalos de uma semana, com $100 \mu \mathrm{g}$ de vírus purificado em cada uma, mostrou-se eficiente para induzir resposta de imunidade nos animais. Embora não existam regras especificas sobre a melhor rota de injeção, nem sobre a quantidade de vírus utilizada em cada injeção, a concentração usada no presente trabalho ficou aquém da geralmente relatada em procedimentos de produção de anticorpos contra vírus de plantas (Van Regenmortel, 1982 e Ball et al.,1990). Esses autores apontam imunizações com concentrações de vírus variando de 0,3 a 46,2 mg. De acordo com Van Regenmortel (1982), a injeção de grandes quantidades de vírus não induz a maior produção de anticorpos. Segundo esse mesmo autor, muitos pesquisadores, por questão de segurança, injetam quantidades de antígeno bem maiores do que as necessárias para a 
indução da produção de anticorpos pelo animal. Esta prática tem a desvantagem de que, juntamente com o antígeno, também pode estar sendo injetada uma concentração elevada de contaminantes que induzem a produção de anticorpos inespecíficos.

O uso de pequenas concentrações de antígeno (200 a $350 \mu \mathrm{g})$ para a produção de anticorpos em coelhos, contra o "barley yellow dwarf virus", foi relatado por Rochow et al., (1971) e Aapola \& Rochow (1971) com resultados satisfatórios.

Os anticorpos contra o PWV produzidos em galinha foram facilmente extraídos diretamente da gema dos ovos, utilizando-se a metodologia de Polson et al. (1980). É importante lembrar que a gema do ovo tem a vantagem de conter apenas a $\lg Y$, mas não as $\operatorname{lgM}$ e $\lg A$ (Rose et al.,1974). A concentração de lgY obtida foi de $6,25 \mathrm{mg} / \mathrm{ml}$ por gema. Polson et al. (1980) relataram a obtenção de concentrações de $\mathrm{lgY}$ variando de $6-12 \mathrm{mg} / \mathrm{ml}$ por gema. Em outro trabalho, Hu et al. (1985) relataram a produção de $5 \mathrm{mg} / \mathrm{ml}$ de $\lg G$ (IgY) contra o isolado SGV do "barley yellow dwarf virus" por gema.

A produção de anticorpos em coelhos, bem como a purificação da lgG a partir de antissoro bruto não apresentaram dificuldades e os resultados obtidos foram semelhantes aos relatados na literatura para outros virus de plantas (Van Regenmortel, 1982).

\subsection{Padronização do DAS-ELISA indireto}

Para a padronização do DAS-ELISA indireto foram testadas diferentes concentrações de IgG e de lgY, utilizando-se a IgG para a captura do antígeno e a IgY para completar o sanduíche da reação sorológica, e vice-versa. De uma maneira geral observou-se que, independente da concentração ou da posição 
das imunoglobulinas, o DAS-ELISA indireto foi sensivel para a detecção de partículas do PWV e permitiu separar nitidamente as reações positivas das negativas (Figuras 4 e 5). Deve-se lembrar que uma reação foi considerada positiva quando o valor da absorbância obtido para a amostra contendo o vírus foi superior a duas vezes a absorbância do extrato de planta sadia. No entanto, a sensibilidade do DAS-ELISA indireto foi bem superior quando a IgG foi utilizada para a captura do antígeno e a lgY usada para completar a reação sorológica (Figura 4), do que quando usadas em posições invertidas (Figura 5). $\mathrm{Na}$ primeira configuração, os valores de absorbância das amostras contendo o vírus foram de 9 a 55 vezes superiores ao dobro da absorbância dos extratos de plantas sadias. A maior diferença foi encontrada quando utilizou-se $10 \mu \mathrm{g} / \mathrm{ml}$ de lgG e $1 \mu \mathrm{g} / \mathrm{ml}$ de $\mathrm{lgY}$. Esses valores, conforme mencionado anteriormente, foram escolhidos como padrões para os testes com o PWW. Os valores aqui encontrados estão de acordo com Van Regenmortel \& Dubs (1993), que recomendam concentrações de 1 a $20 \mu \mathrm{g} / \mathrm{ml}$ da imunoglobulina para a captura do antígeno e de 0,1 a $2 \mu \mathrm{g} / \mathrm{ml}$ da imunoglobulina para completar a reação sorológica. Os resultados desses testes não permitem elucidar o(s) fator(es) que faz(em) com que a primeira configuração do DAS-ELISA indireto seja mais sensivel do que a segunda.

\subsection{Sensibilidade do DAS-ELISA indireto}

Clark \& Adams (1977) foram os primeiros a demonstrarem a eficiência da técnica sorológica de ELISA para a deteç̧ão de vírus de plantas e diagnóstico de fitoviroses. Desde então, muitas variações do procedimento básico de ELISA foram desenvolvidas, com o objetivo principal de otimizar o teste para fins específicos. De uma maneira geral, as diferentes variações do 
teste de ELISA têm se mostrado bastante sensiveis, permitindo a detecção de concentrações de vírus da ordem de 1 a $10 \mathrm{ng} / \mathrm{ml}$ (Van Regenmortel, 1982; Matthews, 1991 e Van Regenmortel \& Dubs, 1993).

Embora não parece haver relatos sobre a sensibilidade da técnica de DAS-ELISA indireto, que utiliza anticorpos produzidos em duas espécies de animais, os resultados obtidos no presente trabalho estão de acordo com o relatado na literatura para outras variações da técnica de ELISA. O DAS-ELISA indireto mostrou-se bastante sensivel para a detecção do PWV, quando utilizou-se como padrão de separação o dobro da absorbância da amostra de planta sadia. Nesses casos foi possivel detectar concentrações do PWV de até $20 \mathrm{ng} / \mathrm{ml}$. Esse resultado permite sugerir com segurança a utilização dessa técnica para fins de deteç̧ão do PWV e para o diagnóstico do mosaico causado por esse vírus. Além da alta sensibilidade, outra vantagem dessa técnica é a de que a utilização de anticorpos produzidos em duas espécies de animais, elimina a chance de reação cruzada entre a IgG (utilizada na captura do antígeno) e a imunoglobulina conjugada com a fosfatase alcalina, que reconhece a $\lg Y$, reduzindo assim a chance de falsos positivos. Isto ocorre porque os anticorpos produzidos em galinha não apresentam reação cruzada com imunoglobulinas de mamiferos (Van Regenmortel, 1982). Acrescenta-se a estas as demais vantagens já conhecidas dos testes de ELISA que são: rapidez, baixo custo e avaliação de um grande número de amostras ao mesmo tempo.

\subsection{Estimativa da concentração do PWV}

A possibilidade de utilização do DAS-ELISA indireto para estimar a concentração do PWV em tecidos de plantas foi inicialmente avaliada com concentrações conhecidas do vírus purificado. Os testes preliminares com 
concentrações variando de 10 a $5.120 \mathrm{ng} / \mathrm{ml}$ do $\mathrm{PWV}$ indicaram que na faixa de 40 a $2.560 \mathrm{ng} / \mathrm{ml}$ houve uma alta correlação de linearidade $\left(R^{2}=0,9973\right)$ entre a concentração do vírus e os valores de absorbância a $405 \mathrm{~nm}$ (Figura 7). Em função dessa alta correlação entre essas variáveis, foi possível estabelecer uma equação de regressão linear que mostrou-se adequada para estudos de estimativa da concentração do PWV presente em amostras de plantas infectadas. Resultados semelhantes foram obtidos com concentrações conhecidas do TMV (Cardin et al., 1983 e Devash et al., 1982) e do CMV (Cardin et al., 1984).

A utilização prática do DAS-ELISA indireto para estimar a concentração do PWV foi demonstrada em estudos realizados com plantas de Passsiflora edulis f. flavicarpa, P. giberti, P. cincinnata, Crotalaria juncea e Phaseolus vulgaris cv. Black Turtle 2 inoculadas com três isolados do vírus.

De uma maneira geral constatou-se que a técnica utilizada permitiu detectar grandes variações na concentração do vírus, principalmente em plantas do gênero Passiflora. Embora o objetivo principal desse trabalho tenha sido apenas o de avaliar a efetividade do DAS-ELISA indireto para quantificação do PWV, é interessante especular que as variações observadas entre as plantas de Passiflora podem estar associadas à variabilidade genética do gênero, uma vez que trata-se de plantas obrigatoriamente de polinização cruzada (Bruckner, 1994). No caso das plantas de $C$. juncea e de $P$. vulgaris $\mathrm{cv}$. Black Turtle 2, apesar de o DAS-ELISA indireto também ter sido eficiente para detectar variações nas concentrações do PWV, estas foram bem menores do que as observadas em plantas de Passiflora. Nesse caso, é possivel que parte dessa menor variabilidade esteja relacionada com a maior uniformidade genética das espécies.

Análise de correlação entre concentração do PWV nos tecidos das plantas testadas e severidade dos sintomas indicou haver uma correlação positiva e significativa na maioria das combinações planta/vírus. Exceção das 
plantas de $P$. edulis f. flavicarpa inoculadas com o isolado Vera Cruz no período de verão (Figura 8, Quadro 1), onde não foi obtida correlação estatística significativa, embora observa-se que as plantas com notas de sintomas mais altas geralmente continham maior quantidade de vírus. Esses resultados estão de acordo com diversos trabalhos que relataram a existência de correlação direta entre a severidade dos sintomas e a concentração do vírus na planta (Bancroft, 1958; Bancroft \& Pound, 1956; Cheo \& Pound, 1952; Foster \& Webb, 1965; Pound \& Helms, 1955), embora exemplos opostos existam em função da combinação planta/vírus (Foster \& Webb, 1965 e Pound \& Weathers, 1953).

Os resultados desse trabalho indicam a possibilidade de utilização da técnica de DAS-ELISA indireto para trabalhos de seleção preliminar de plantas de maracujazeiro resistentes elou tolerantes ao PWV, com base na estimativa da concentração do vírus nos tecidos das plantas e na sintomatologia. A utilização da estimativa da concentração do vírus em trabalhos de melhoramento para resistência de plantas a vírus foi recomendada em diversos trabalhos (Almeida, 1995a; Gibb et al., 1989; Hunger et al., 1989; Kuhn et al., 1986; Michelson et al., 1994; Murphy \& Kyle, 1995 e Pink et al., 1992), embora em alguns casos, esse parâmetro apenas, não foi satisfatório para tal propósito (Myers et al., 1993; Hunger \& Sherwood, 1985; Hunger et al., 1991; Hunger et al., 1992 e Lapidot et al., 1997). No caso do maracujazeiro, por se tratar de uma planta semi-perene, recomenda-se que a seleção preliminar de plantas com base nas avaliações de concentração do vírus e nos sintomas seja complementada através de estudos de desenvolvimento e de produção em condições de campo.

Embora não tenha sido objetivo desse trabalho avaliar o efeito da época da inoculação das plantas na concentração do PWV e na severidade dos sintomas, os dados obtidos com as plantas de $P$. edulis f. flavicarpa inoculadas com o isolado de Vera Cruz indicaram que as inoculadas no período de inverno (Figura 9) apresentaram concentrações de vírus nos tecidos inferiores àquelas 
inoculadas no verão (Figura 8). Esse fato merece futuras investigações e deve ser levado em consideração em trabalhos posteriores que visam a utilização do DAS-ELISA indireto na seleção preliminar de plantas de maracujazeiro resistentes ou tolerantes à doença. O efeito de diferentes temperaturas na concentração de vírus e na expressão de sintomas já foi relatado para diversas combinações vírus/planta (Foster \& Webb, 1965 e Lebeurier \& Hirth, 1966).

A seleção de plantas cuja tolerância esteja associada com uma menor concentração do PWV nos tecidos, poderá oferecer dois tipos de beneficios em termos de controle da doença em campo. A tolerância, por si, poderá permitir um melhor desenvolvimento das plantas bem como uma maior produção de frutos comerciais. Além disso, a menor quantidade de vírus presente nos tecidos poderá afetar a epidemiologia da doença em campo, especialmente na velocidade de disseminação do vírus dentro da cultura. Barker \& Harrison (1986) mostraram que a eficiência na transmissão do "potato leafroll virus"PLRV por afídeos, estava relacionada com a concentração do vírus nos tecidos de plantas de batata. A maior eficiência de transmissão foi conseguida quando utilizadas cultivares suscetíveis como fonte de inóculo, atingindo taxas de transmissão de 26 a $78 \%$, enquanto que taxas de 2 a $37 \%$ foram conseguidas quando utilizou-se cultivares resistentes. Resultados semelhantes foram demonstrados por Souza-Dias (1988) estudando o mesmo vírus em batata. Após um período de nove horas de aquisição do vírus pelo vetor, houve uma eficiência de transmissão de 50 \% quando utilizado o cultivar suscetível Russet Burbank como fonte de inóculo. Entretanto, quando utilizado o cultivar resistente Katahdin, a eficiência de transmissão do PLRV por afídeos foi de 33 \%. Essa relação da influência da concentração do vírus nos tecidos da plantas na eficiência de transmissão por afídeos também já foi demonstrada em outros trabalhos. (Barker \& Harrison, 1985; Foxe \& Rochow, 1975 e Zitter, 1975). 


\section{CONCLUSÕES}

Diante dos resultados obtidos concluiu-se que:

1 - A configuração mais adequada do DAS-ELISA indireto para fins de diagnóstico e estudos quantitativos do PWV foi obtida utilizando-se $10 \mu \mathrm{g} / \mathrm{ml}$ da IgG para a captura do antígeno (PWV) e $1 \mu \mathrm{g} / \mathrm{ml}$ da $\lg Y$ para completar o sanduíche da reação sorológica;

2 - O DAS-ELISA indireto foi altamente sensivel, permitindo a deteç̧ão de até $20 \mathrm{ng}$ do PWV por $\mathrm{ml}$;

3 - O DAS-ELISA indireto permitiu a quantificação do PWV em tecidos de plantas infectadas. 


\section{REFERÊNCIAS BIBLIOGRÁFICAS}

AAPOLA, A.I.E.; ROCHOW, W.F. Relationships among three isolates of barley yellow dwarf virus. Virology, v.46, p.127-141, 1971.

ALMEIDA, A.M.R. Evaluation of soybean tolerance to soybean mosaic virus. Fitopatologia Brasileira, v.20, n.1, p.24-29, 1995a.

ALMEIDA, A.M.R. Noções de sorologia aplicadas à fitovirologia. Londrina: EMBRAPA, 1995b. 105p.

ANDERSON, E.J.; KLINE, A.S.; MORELOCK, T.E.; McNEW, R.W. Tolerance to blackeye cowpea mosaic potyvirus not correlated with decreased virus accumulation or protection from cowpea stunt disease. Plant Disease, v.80, p.847-852, 1996.

BALL, E.M.; HAMPTON, R.; DE BOER, S.H.; SCHAAD, N.W. Policlonal antibodies. In: HAMPTON, R.; BALL, E.M.; DE BOER, S.H. (Ed.) Serological methods for detection and identification of viral and bacterial plant pathogens. St. Paul: APS Press, 1990. p.33-54. 
BANCROFT, J.B. Temperature and temperature-light effects on the concentration of squash mosaic virus in leaves of growing cucurbits. Phytopathology, v.48, p.98-102, 1958.

BANCROFT, J.B.; POUND, G.S. Cumulative concentrations of tobacco mosaic virus in tobacco and tomato at different temperatures. Virology, v.2, p.2943, 1956.

BARKER, H.; HARRISON, B.D. Restricted multiplication of potato leafroll virus in resistant potato genotypes. Annals of Applied Biology, v.107, p.205212, 1985.

BARKER, H.; HARRISON, B.D. Restricted distribution of potato leafroll virus antigen in resistant potato genotypes and its effect on transmission of the virus by aphids. Annals of Applied Biology, v.109, p.595-604, 1986.

BEZERRA, D.R.; LIMA, J.A.A.; XAVIER FILHO, J. Purificação e caracterização de um isolado cearense do vírus do endurecimento dos frutos do maracujazeiro. Fitopatologia Brasileira, v.20, p.553-560, 1995.

BRUCKNER, C.H. Auto-incompatibilidade em maracujazeiro. In: SÃO JOSÉ, A.R. (Ed.) Maracujá: produção e mercado. Vitória da Conquista, UESB, 1994. p.6-18.

CARDIN, L.; DEVERGNE, J.C.; PITRAT, M. Dosage immunoenzymatique (ELISA) du virus de la mosaïque du concombre. I. Aspect méthodologique. Agronomie, v.4, p.125-135, 1984. 
CARDIN, L.; SALLE, D.; POUPET, A.; PONCHET, M. Dosage immunoenzymatique du virus de la mosaïque du tabac dans différents tissus de tabac cultivés "in vitro". Agronomie, v.3, p.983-988, 1983.

CHAGAS, C.M.; KITAJIMA, E.W.; LIN, M.T.; GAMA, M.I.C.S.; YAMASHIRO, T. Grave moléstia em maracujá amarelo (Passiflora edulis f. flavicarpa) no Estado da Bahia, causado por um isolado do vírus do "woodiness" do maracujá. Fitopatologia Brasileira, v.6, p.259-268, 1981.

CHAGAS, C.M.; REZENDE, J.A.M.; COLARICCIO, A.; PIZA Jr., C.T.; LOPES, L.C.; GALLETTI, S.R.; FERRARI, J.T.; BELLUZI, B.M. Ocorrência do endurecimento do fruto do maracujazeiro (VEFM) no Estado de São Paulo. Revista Brasileira de Fruticultura, v.14, p.187-190, 1992.

CHANG, C.A.; LIN, Y.D.; LIN, H.H. Utilization of virus-free passionfruit seedling control passionfruit virus disease in Taiwan. Proceeding of disease and pest control without pesticide. 1992. p.349-359.

CHEN, M.C. The nucleotide sequence of the 3-terminal region of passionfruit woodiness virus. Taichung, 1992. 52p. Thesis (Master) - National Chung Hsing University.

CHEO, P.C. Subliminal infection of cotton by tobacco mosaic virus. Phytopathology, v.60, n.1, p.41-46, 1970.

CHEO, P.C.; POUND, G.S. Relation of air temperature, soil temperature, photoperiod, and light intensity to the concentration of cucumber virus 1 in spinach. Phytopathology, v.42, p.306-310, 1952. 
CLARK, M.F.; ADAMS, A.N. Characteristics of the microplate method of enzime-linked immunosorbent assay for the detection of plant viruses. Journal of General Virology, v.34, p.475-483, 1977.

COSTA, A.F. Contribuição ao estudo da epidemiologia e controle do virus do endurecimento dos frutos do maracujá. In: CONGRESSO DA SOCIEDADE BRASILEIRA DE FITOPATOLOGIA, 18., Fortaleza, 1985. Resumos. Fitopatologia Brasileira, v.10, n.2, p.310, 1985.

COSTA, A.F. Pesquisa e extensão com maracujá em Pernambuco. In: SÃO JOSÉ, A.R. (Ed.) Maracujá: produção e mercado. Vitória da Conquista: UESB, 1994. p.138-143.

DAVERGNE, J.C.; CARDIN, L.; PITRAT, M.; LECOQ, H. Dosage immunoenzymatique (ELISA) du virus de la mosaïque du concombre. II. Multiplication comparée du virus dans des melons sensibles et résistants. Agronomie, v.4, p.137-147, 1984.

DERRICK, K.S. Quantitative assay for plant viruses using serologically specific eletron microscopy. Virology, v.56, p.652-653, 1973.

DEVASH, Y.; BIGGS, A.N.; SELA, I. Multiplication of tobacco mosaic virus in tobacco leaf disks is inhibited by $\left(2^{\prime}-5^{\prime}\right)$ oligoadenylate. Science, v.216, p.1415-1416, 1982.

FOSTER, R.E.; WEBB, R.E. Temperature effects on symptom expression and concentration of six muskmelon viruses. Phytopathology, v.55, p.981-984, 1965. 
FOXE, M.J.; ROCHOW, W.F. Importance of virus source leaves in vector specificity of barley yellow dwarf virus. Phytopathology, v.65, p.1124-1129, 1975 .

GIBB, K. S.; HELLMANN, G.M.; PIRONE, T.P. Nature of resistance of a tobacco cultivar to tobacco vein mottling virus. Molecular Plant-Microbe Interactions, v.2, n.6, p.332-339, 1989.

GOKHALE, D.V.; BALD, J.G. Relationship between plant virus concentration and infectivity: a 'growth curve' model. Journal of Virological Methods, v.18, p.225-232, 1987.

GOMES, F.P. Curso de estatística experimental, 13. ed. Piracicaba: Nobel, 1990. $468 p$.

HILL, S.A. Methods in plant virology. Oxford: Blackwell, 1984. 167p.

HU, J.S.; ROCHOW, W.F.; DIETERT, R.R. Production and use of antibodies from hen eggs for the SGV isolate of barley yellow dwarf virus. Phytopathology, v.75, n.8, p.914-919, 1985.

HUNGER, R.M.; SHERWOOD, J.L. Use of sintomatology and virus concentration for evaluating resistance to wheat soilborne mosaic virus. Plant Disease, v.69, n.10, p.848-850, 1985.

HUNGER, R.M.; ARMITAGE, C.R.; SHERWOOD, J.L. Effects of soilborne mosaic virus on hard red winter wheat. Plant Disease, v.73, n.12, p.949952, 1989. 
HUNGER, R.M.; SHERWOOD, J.L.; SMITH, E.L.; ARMITAGE, C.R. Symptomatology and enzyme-linked immunosorbent assay used to facilitate breeding for resistance to wheat soilborne mosaic. Crop Science, v.31, p.900-905, 1991.

HUNGER, R.M.; SHERWOOD, J.L.; EVANS, C.K.; MONTANA, J.R. Effects of planting date and inoculation date on severity of wheat streak mosaic in hard red winter wheat cultivars. Plant Disease, v.76, n.10, p.1056-1060, 1992.

INCH, A.J. Passionfruit diseases. Queensland Agricultural Journal, p.479484, sep./out. 1978.

INOUE, A.K.; MELLO, R.N.; NAGATA, T.; KITAJIMA, E.W. Characterization of passionfruit woodiness virus isolates from Brasilia and surrounding region, Brazil. Fitopatologia Brasileira, v.20, n.3, p.479-487, 1995.

KITAJIMA, E.W.; CHAGAS, C.W.; CRESTANI, O. A. Enfermidades de etiologia viral e associadas a organismos do tipo micoplasma em maracujazeiro no Brasil. Fitopatologia Brasileira, v.11, p.409-432, 1986.

KLECZKOWSKI, A. Interpreting relationships between the concentrations of plant viruses and numbers of local lesions. Jounal of Microbiology, v.4, p.53-69, 1950.

KUHN, C.W.; BENNER, C.P.; HOBBS, H.A. Resistance responses in cowpea to southern bean mosaic virus based on virus accumulation and symptomatology. Phytopathology, v. 76, n.8, p.795-799, 1986. 
LAPIDOT, M.; PARAN, I.; BEN-JOSEPH, R.; BEN-HARUSH, S.; PILOWSKY, M.; COHEN, S.; SHIFRISS, C. Tolerance to cucumber mosaic virus in pepper: development of advanced breeding lines and evaluation of virus level. Plant Disease, v.81, n.2, p.185-188, 1997.

LEBEURIER, G.; HIRTH, L. Effect of elevated temperatures on the development of two strains of tobacco mosaic virus. Virology, v.29, p.385395, 1966.

LORETO, T.J.G.; VITAL, A. Viroses e micoplasmoses do maracujá em Pernambuco. Informe SERDV, 1983. 23p.

MARINHO, V.L.A.; KITAJIMA, E.W. Um método simplificado de purificação de potyvirus. Fitopatologia Brasileira, v.14, p.91-93, 1989.

MARINHO, V.L.A.; LIN, M.T.; KITAJIMA, E.W. CRESTANI, O.A. Purificação do vírus do endurecimento do fruto do maracujazeiro e produção de anti-soros específicos. In: CONGRESSO DA SOCIEDADE BRASILEIRA DE FITOPATOLOGIA, 17., São Paulo, 1984. Resumos. Fitopatologia Brasileira, v.9, n.2, p.414, 1984.

MATTHEWS, R.E.F. Plant virology. New York: Academic Press, 1991. 835p.

McKNIGHT, T. The woodiness virus of the passion vine (Passiflora edulis Sims.). Queensland Journal of Agricultural Science, v.10, p.4-35, 1953. 
MICHELSON, I.; ZAMIR, D.; CZOSNEK, H. Accumulation and translocation of tomato yellow leaf curl virus (TYLCV) in a Lycopersicon esculentum breeding line containing the $L$. chilense TYLCV tolerance gene Ty-1. Phytopathology, v.84, n.9, p.928-933, 1994.

MOORE, D.L.; LISTER, R.M.; ABNEY, T.S.; ATHOW, K.L. Evaluation of virus contents in soybean by enzyme-linked immunosorbent assay. Plant Disease, v.66, n.9, p.790-793, 1982.

MOYER, J.W.; KENNEDY, G.G.; ROMANOW, L.R. Resistance to watermelon mosaic virus II multiplication in Cucumis melo. Phytopathology, v.75, n.2, p.201-205, 1985.

MURPHY, F.A.; FAUQUET, C.M.; BISHOP, D.H.L.; GHABRIAL, S.A.; JARVIS, A.W.; MARTELLI, G.P.; MAYO, M.A.; SUMMERS, M.D. Virus taxonomy: classification and nomenclature of viruses; sixth report of the International Committee on Taxonomy of Viruses. New York: Spring Verlag, 1995. 568p.

MURPHY, J.F.; KYLE, M.M. Alleviation of restricted systemic spread of pepper mottle potyvirus in Capsicum annuum cv. Avelar by coinfection with a cucumovirus. Phytopathology, v.85, n.5, p.561-566, 1995.

MYERS, L.D.; SHERWOOD, J.L.; SIEGERIST, W.C.; HUNGER, R.M. Temperature-influenced virus movement in expression of resistance to soilborne wheat mosaic virus in hard red winter wheat (Triticum aestivum). Phytopathology, v.83, n.5, p.548-551, 1993.

NOORDAM, D. Identification of plant viruses: methods and experiments. Wageningen: Centre for Agricultural Publishing Documentation, 1973. 207p. 
PARES, R.D.; MARTIN, A.B.; FITZELL, R.D. Virus-induced tip necrosis of passionfruit (Passiflora edulis Sims.). Australian Plant Pathology, v.14, p.76-78, 1985.

PEASLEY, D.; FITZELL, R.D. Passionfruit industry benefits through scion wood scheme. Agriculture Gazette, v.92, p.5-8, 1981.

PINK, D.A.C.; LOT, H.; JOHNSON, R. Novel pathotypes of lettuce mosaic virus - breakdown of a durable resistance?. Euphytica, v.63, p.169-174, 1992.

PIO-RIBEIRO, G.; MARIANO, R.L.R. Doenças do maracujazeiro (Passiflora spp). In: KIMATI, H.; AMORIM, L.; BERGAMIN FILHO, A.; CAMARGO, L.E.A.; REZENDE, J.A.M. (Ed.) Manual de fitopatologia, 3. ed. São Paulo: Agronômica Ceres, 1997. vol 2: Doenças das plantas cultivadas: p.525-534.

POLSON, A.; VON WECHMAR, M.B; VAN REGENMORTELL, M.H.V. Isolation of viral $\lg Y$ antibodies from yolks of immunized hens. Immunological Communications, v.9, p.475-493,1980.

POUND, G.S.; HELMS, K. Effects of temperature on multiplication of potato virus $X$ in nicotiana species. Phytopathology, v.45, p.493-499, 1955.

POUND, G.S.; WEATHERS, L.G. The effects of air and soil temperatures on the multiplication of turnip virus 1 in certain nicotiana species. Phytopathology, v.43, p.550-554, 1953.

REZENDE, J.A.M. Doenças de vírus e micoplasma do maracujazeiro no Brasil. In: SÃO JOSÉ, A.R. (Ed) Maracujá: produção e mercado. Vitória da Conquista, UESB, 1994. p.116-125. 
REZENDE, J.A.M.; SHERWOOD, J.L. Breakdown of cross protection between strains of tobacco mosaic virus due to susceptibility of dark green areas to superinfection. Phytopathology, v.81, n.12, p.1490-1495, 1991.

ROCHOW, W.F.; AAPOLA, A.I.E.; BRAKKE, M.K.; CARMICHAEL, L.E. Purification and antigenicity of three isolates of barley yellow dwarf virus. Virology, v.46, p.117-126, 1971.

ROSE, M.E.; ORLANS, E.; BUTTRESS, N. Immunoglobulin classes in the hen's egg: their segregation in yolk and white. European Journal Immunological, v.4, p-521-523, 1974.

RUGGIERO, C.; SÃO JOSÉ, A.R.; KAVATI, R. Maracujá para exportação: aspectos técnicos da produção. Brasília: FRUPEX, 1996. 64p.

SALOMÃO, T.A.; ANDRADE, V.M.M. Botânica. In: RUGGIERO, C. (Ed.) Cultura do maracujazeiro. Ribeirão Preto: Legis Summa, 1987. p.20-39.

SÃO JOSÉ, A.R.; REZENDE, J.A.M.; COSTA, A.F. Ocorrência do vírus do endurecimento do fruto do maracujazeiro no Norte do Estado de Minas Gerais. In: CONGRESSO BRASILEIRO DE FRUTICULTURA, 13., Salvador, 1994. Anais. Salvador: SBF, 1994. p. 797.

SAS INSTITUTE. SAS/STAT user's guide: release 6.08. ed. Cary, 1993.

SIMMONDS, J.H. Mild strain protection as a means of reducing losses from the Queensland woodiness virus in the passion vine. Queensland Journal of Agricultural Science, v.16, p.371-380, 1959. 
SOUZA-DIAS, J.A.C. The relationships of potato leafroll virus concentration in the host and vector to disease spread. Madison, 1988. 339p. Thesis (Ph.D.)-University of Wisconsin.

SUTULA, C.L.; GILLETT, J.M.; MORRISSEY, S.M.; RAMSDELL, D.C. Interpreting ELISA data and establishing the positive-negative threshold. Plant Disease, v.70, n.8, p.722-726, 1986.

TAYLOR, R.H.; GREBER, R.S. Passion fruit woodiness virus. CMIIAAB, Description of Plant Viruses $n^{\circ} 122,1973$.

VAN REGENMORTEL, M.H.V. Serology and immunochemistry of plant viruses. New York: Academic Press, 1982. 302p.

VAN REGENMORTEL, M.H.V; DUBS, M.C. Serological procedures. In: MATTHEWS, R.E.F. (Ed.) Diagnosis of plant virus diseases. Boca Raton: CRC Press, 1993. cap.7, p. 159-214.

YAMASHIRO, T.; CHAGAS, C.M. Ocorrência de grave virose em maracujá amarelo (Passiflora edulis f. flavicarpa Deg.) no Estado da Bahia. In: CONGRESSO BRASILEIRO DE FRUTICULTURA, 5. Pelotas, 1979. Anais. Pelotas:SBF, 1979. p.915-917.

ZITTER, T.A. Transmission of pepper mottle virus from susceptible and resistant pepper cultivars. Phytopathology, v.65, p.110-114, 1975. 


\section{APÊNDICE}




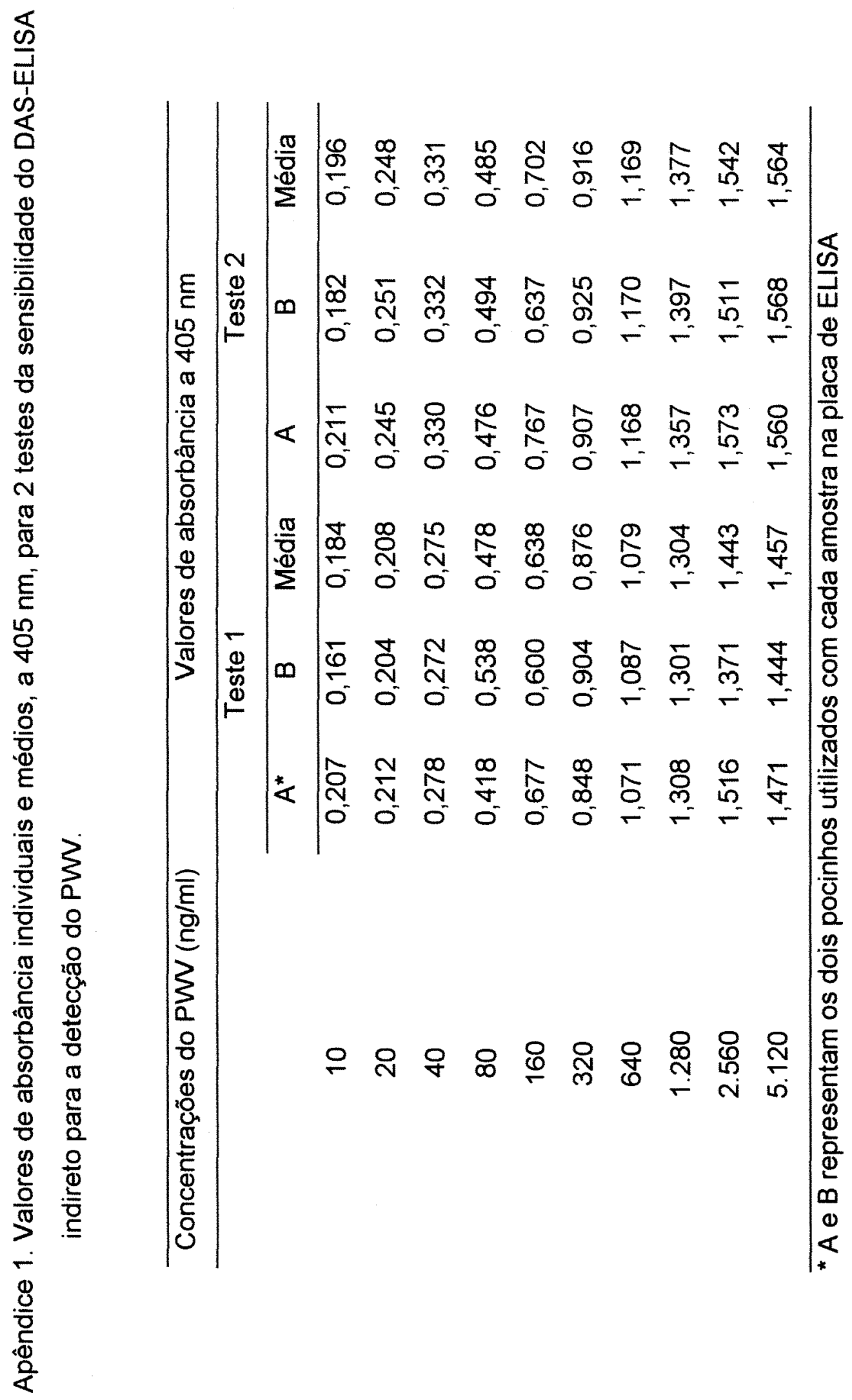


$\stackrel{8}{8}$

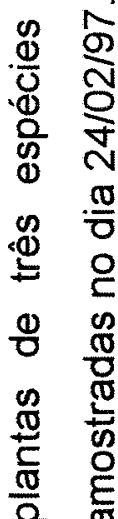

(1) 0

\&

E

유 음

(1)

क

물

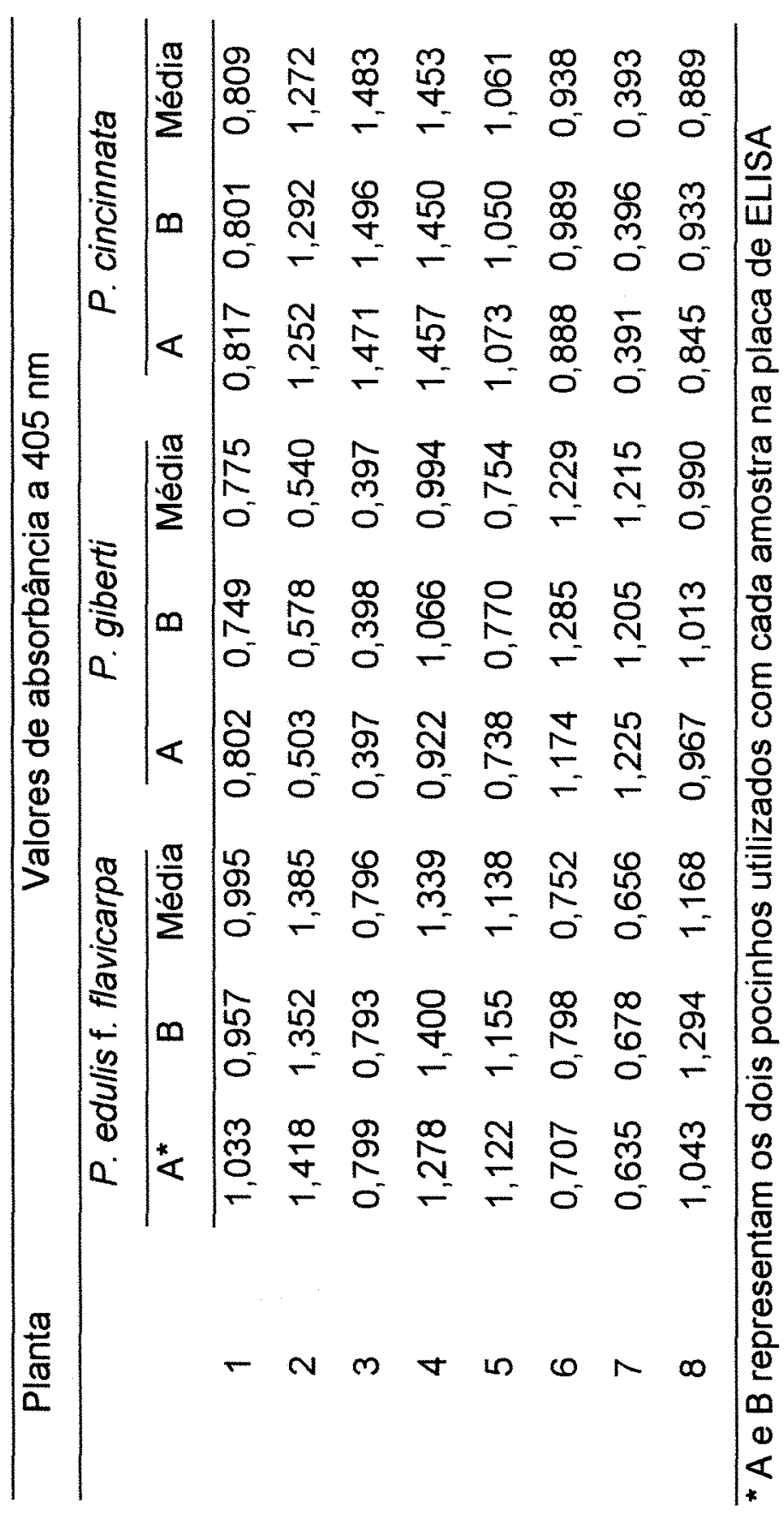

$\frac{8}{0}$
$\frac{0}{0}$
$\frac{1}{0}$
$\frac{0}{4}$ 

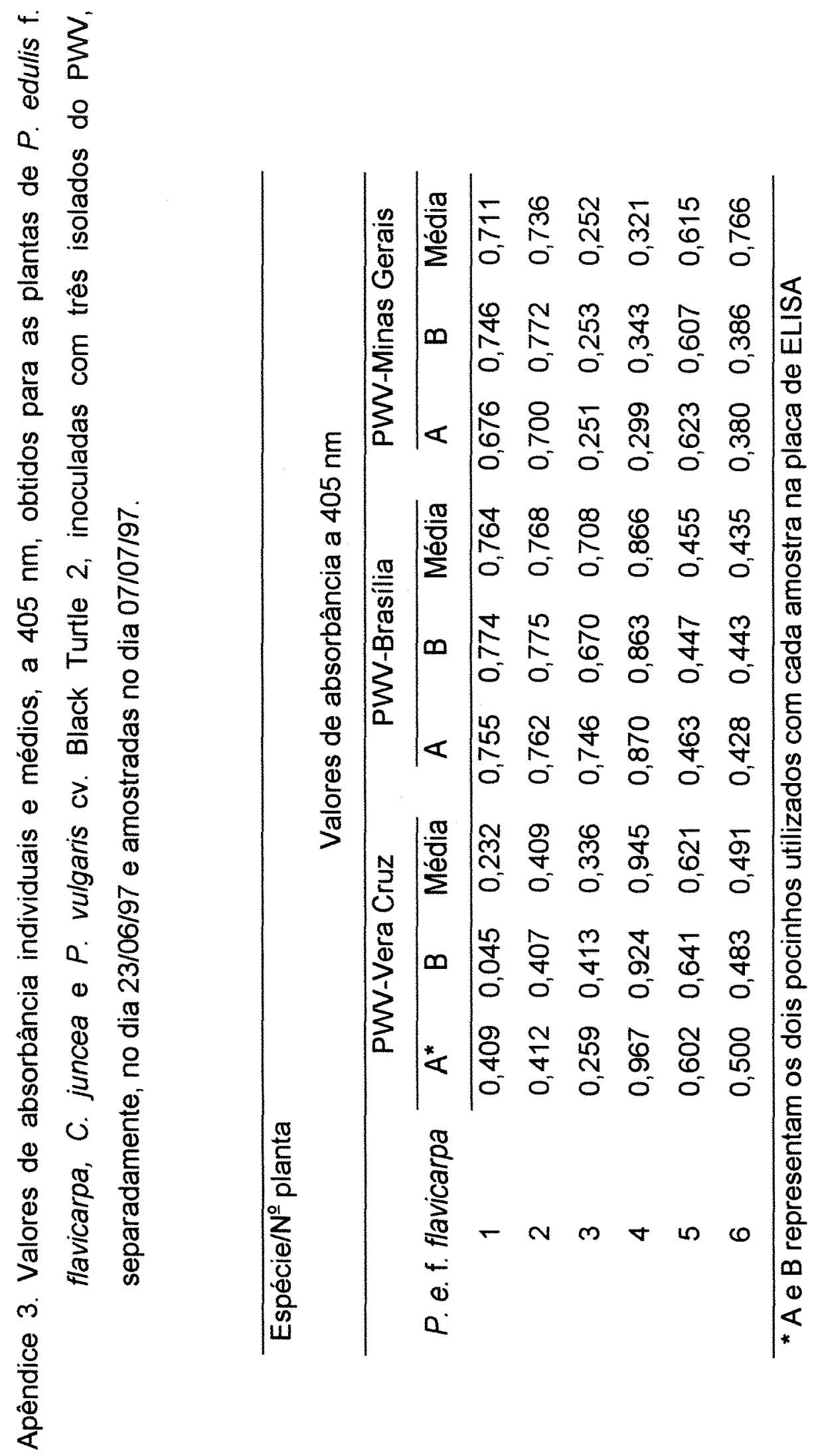


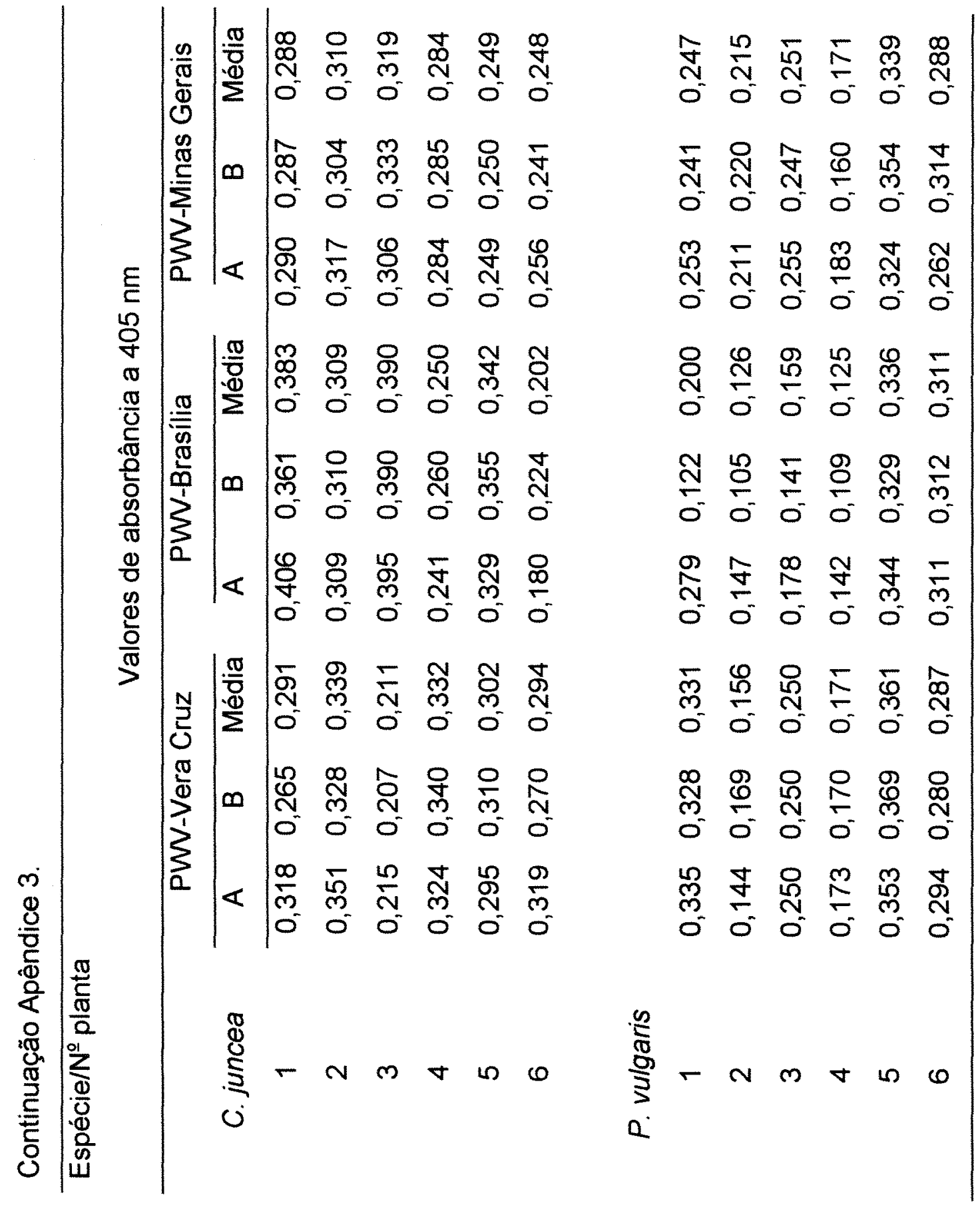

